AperTO - Archivio Istituzionale Open Access dell'Università di Torino

\title{
"Veiling The Controversies with Dubious Moral Attitudes"? Creditors and Debtors in Keynes's Ethics of International Economic Relations
}

\section{This is the author's manuscript}

Original Citation:

Availability:

This version is available http://hdl.handle.net/2318/119669

since

Terms of use:

Open Access

Anyone can freely access the full text of works made available as "Open Access". Works made available under a Creative Commons license can be used according to the terms and conditions of said license. Use of all other works requires consent of the right holder (author or publisher) if not exempted from copyright protection by the applicable law. 


\title{
Quaderni SEMeQ
}

\author{
A. Carabelli - M. Cedrini \\ VEILING THE CONTROVERSIES WITH \\ DUBIOUS MORAL ATTITUDES? \\ Creditors and Debtors in Keynes's Ethics of \\ International Economic Relations
}

Novembre 2010

Quaderno n. 12/2010 
Stampato in proprio presso la Segreteria del Dipartimento di Scienze Economiche e Metodi Quantitativi, Università degli Studi del Piemonte Orientale "A. Avogadro"

I Lavori pubblicati nella collana riflettono esclusivamente le opinioni degli autori e non impegnano la responsabilità del Dipartimento SEMeQ.

Dipartimento di Scienze Economiche e Metodi Quantitativi

Via E. Perrone 18 - 28100 Novara

Tel. 39 (0) 321- $375310 \quad$ Fax 39 (0) 321 - 375305

e-mail: segreteria.dsemeq@unipmn.it 


\title{
Veiling The Controversies With Dubious Moral AtTitudes? \\ Creditors and Debtors in Keynes's Ethics \\ of International Economic Relations
}

\section{Anna M. Carabelli* \& Mario A. Cedrini**}

\begin{abstract}
This paper addresses the enduring insistence on the moral dimension of international economic relations in Keynes's economics and diplomacy. The issue has so far raised scarce attention in the literature, which tend to attribute some outstanding failures of Keynes's economic diplomacy to the presumed instrumental use Keynes made of moral arguments. The paper provides a comprehensive account of the ethical arguments used by Keynes in his lifelong attempt to design a fair international order, and aims to demonstrate that this moral dimension is part of a welldefined ethics of international relations which privileges national policy space and freedom to choose.
\end{abstract}

Keywords: John Maynard Keynes, international economic relations, ethics, complexity. JEL codes: B31, B40, F02, F5, A13

Previous versions of this paper have been presented at the VII National Conference of the Italian Association for the History of Political Economy (STOREP), Università di Trento, 31 May 2010, and at the 14 Conference of the European Society for the History of Economic Thought (ESHET), University of Amsterdam, 26 March 2010. The authors acknowledge Tonia Warnecke, Annalisa Rosselli and Carlo Cristiano for precious comments. The usual disclaimers apply.

* Dipartimento di Scienze Economiche e Metodi Quantitativi, Università del Piemonte Orientale "Amedeo Avogadro" - Alessandria, Novara, Vercelli. Via Perrone 18, 28100 Novara (Italy), anna.carabelli@eco.unipmn.it.

** Dipartimento di Scienze Economiche e Metodi Quantitativi, Università del Piemonte Orientale "Amedeo Avogadro" - Alessandria, Novara, Vercelli. Via Perrone 18, 28100 Novara (Italy), mario.cedrini@eco.unipmn.it. 


\section{INTRODUCTION}

A remarkable effect of the current global crisis is the revival of interest for the ethics of international economic relations. Only time will tell whether the 'Bretton Woods II' system is a stable configuration of international monetary order or simply a theoretical construction based on the observed characteristics of the delicate U.S.-China duopoly of recent years. For sure, the absence of a coherent set of shared rules for international adjustment, a permanent feature of the international nonsystem which followed the collapse of the Bretton Woods order, is inducing politicians, economists and opinion-makers, in the times of the crisis, to make extensive use of moral arguments when dealing with international economic relations.

Once the moralist Washington Consensus paradigm had finally broken down both as policy prescription for development and as cure for nations hit by the financial crises of the Nineties, a wide spectrum of developing countries chose to adopt unorthodox, gradualist growth strategies based on a mix of current account surpluses, exchange rate undervaluation and reserves accumulation. A huge debate developed about which countries should be blamed for the surge of global imbalances which accompanied this policy shift in emerging markets. Various versions of the 'twin deficits' theory (Chinn 2005) and criticisms of the 'exorbitant privilege' granted to the United States as the international reserve country accused the global debtor of last resort of immoral profligacy. Conversely, Bernanke's (2005) 'global saving glut' theory attributed the rise of global imbalances to developing (particularly Asian) countries' mercantilist strategies. Both these 'made in' interpretations of current account disequilibria (see Carabelli and Cedrini 2010a) guiltily omitted relevant parts of the story, respectively America's role as the locomotive of world growth and the need, for developing countries, to integrate safely into international trade. Hence the success of the systemic 'Bretton Woods II' view about global imbalances, with its generally benevolent disposition toward both surplus and deficit countries.

Yet this enlarged perspective inevitably sheds light on a major shortcoming of our non-system: '[t]he global economy cannot support developing countries' attempt to integrate into the global trading system through export-led development and eliminate international imbalances if developed countries also use export-led growth' (Kregel 2006, p. 171). This line of reasoning may apply also to creditor/debtor relationships in developed regions such as the European Union. Despite Europe's broad external balance, Germany is one of the world's largest surplus country, a consequence of years of export-led growth strategies with sluggish internal demand. Greece is a perfect example of irresponsible debtor, yet a growing number of economists are rather focusing on Germany's policies, when reasoning about the probable consequences of the austerity cure for the continent's financial problems. According to Rodrik (2010), for instance (Roubini 2010 and Soros 2010 take similar stances), 'Germany has to thank deficit countries like the US, or Spain and Greece in Europe, for propping up its industries and preventing its unemployment rate from rising further. For a wealthy economy that is supposed to contribute to global economic stability, Germany is not only failing to do its fair share, but is free-riding on other countries' economies'. Keynes 
seems in the air. Stiglitz (2010) is more explicit: 'Germany (like China) views its high savings and export prowess as virtues, not vices. But John Maynard Keynes pointed out that surpluses lead to weak global aggregate demand - countries running surpluses exert a 'negative externality' on their trading partners. Indeed, Keynes believed that it was surplus countries, far more than deficit countries, that posed a threat to global prosperity'.

After decades of disrepute, Keynes has regained popularity in the times of the global crisis: echoes of a 'Keynes solution' such as the one dealt with in Davidson's latest book (2009) can be found in a remarkable number of analyses of the current situation and proposals for global reform (see for instance Alessandrini and Fratianni 2009). Despite the rediscovery of Keynes's plans for symmetric international adjustment between creditor and debtor countries, still relatively unexplored is exactly the ethics of international economic relations underlying the economist's attempts to design a fair international order. In the paper, we provide a comprehensive account of the ethical arguments used by Keynes in this regard, and revisit, with special concern for the moral and methodological issues involved, some crucial episodes of his economic diplomacy. Our aim is to demonstrate that far from being the weak element in the search for a sounder international political economy, the moral dimension of Keynes's economics and diplomacy helps clarify the essential traits of his desired new global order. More importantly, Keynes's insights into the moral dimension of creditor/debtor relationships at the international level might be of precious help in today's debate about what Stiglitz, among others, calls the 'unacceptable' social and economic consequences of the current arrangements between debtor and creditor countries.

\section{TWO CRITICISMS OF KEYNES'S USE OF MORAL ARGUMENTS IN INTERNATIONAL ECONOMICS}

\section{AND DIPLOMACY}

With few exceptions, the literature has so far given scarce attention to the use made by John Maynard Keynes of moral arguments in some key passages of his economic diplomacy. Economists and historians tend to consider his reiterated insistence on the moral dimension of international economic relations as a weapon of doubtful utility in a context of power politics, where (British) 'brains' cannot compete with (the Americans') 'money bags'. In this framework, Keynes's moral arguments are never examined in their autonomy from other (financial) considerations. They are rather treated, on one hand, as a veil Keynes allegedly attempted to pose on economic obligations to make them less binding or prevent them from working, as in the case of Britain's American debt at the end of World War I. Or, on the other, as an imperfect substitute for finance and purely economic considerations in providing cogency to the line of reasoning underlying Keynes's most imaginative plans, like his proposal for an American gift to Britain in 1945.

The first criticism, which could be named the 'morals as a veil' critique, dates back to a broadcast talk given by Keynes on 3 May 1928, later appeared in New Republic as 'A London View of the War Debts'. On discussing the opportunity to revise the Dawes Plan, Keynes pointed out that due to the complex 
architecture of Inter-Allied indebtedness, a reduction of the maximum annuities Germany should correspond would have made the United States the sole beneficiary of the scheme: in that case, 'many will feel that this is not an outcome tolerable to the sentiments of mankind or in reasonable accord with the spoken professions of Americans when they entered the war or afterwards' (The Collected Writings of John Maynard Keynes, vol. 9, p. 52; hereafter: $\mathrm{CW}$ ). Keynes was there attacking, nine years after his proposal for an all-round cancellation of Inter-Allied debts, the American view of war debts as 'business transactions' (p. 48). Revamping his criticisms to the United States for having used Britain as a 'conduit pipe' (CW 16, p. 279) for American credits to the Allies, Keynes stressed that such debts essentially resulted from America's late entry into war and her inability to help the Allies in any other way than by financial contributions, even for some time after she came into war. The London view of debts was on the contrary that they 'were not made as business transactions and should not be treated as such' (ib.), to the extent that Britain was still ready, if the United States had ceased insisting on debts repayment, to forgo her claims on European countries and her share of Germany reparations in favour of the Allies. The editors of New Republic 'recorded a vigorous dissent' and took issue with Keynes's moral arguments. Although agreeing that both reparations and debt settlements must be scaled down and as a practical matter together, the editors insisted that this must be justified by economic circumstances, rather than the dubious moral attitudes with which Mr Keynes and his associates - so well qualified to urge economic reasons - were veiling the controversỷ' (CW 18, p. 296).

In his Fighting for Britain, Skidelsky (2000) provides a direct illustration of the second kind of criticism - the 'morals rather than finance' critique. In the 1945 memorandum 'Overseas Financial Policy in Stage III', Keynes named 'Justice' his preferred alternative for Britain's economic destiny for the transition to the Bretton Woods order: a general reconsideration of the war burden according to the part effectively had by Britain, the United States and the sterling area countries in financing the war. Both the United States and the sterling countries should have relieved Britain of the debts incurred during the first years of war, and provide her with fresh financial assistance to ease her transition to a financially open world of multilateral free trade. Somehow echoing Edward Playfair's 1941 characterization of Keynes as a too proud or naïve negotiator, inclined to use "moral indignation" as a substitute for business arguments (reported in Moggridge 1992, p. 657), Skidelsky maintains that '[t]he coherence of his memorandum lay in the realm of morals rather than finance. Keynes was using Justice in its classic Aristotelian sense of just desert' (2000, p. 384). Though 'not just a cloak for self-interest', Keynes's morality was certainly 'a vehicle for illusion. The hope for gifts to rescue Britain from the consequences of policy had become by 1945 a necessary illusion the only way of averting the eyes of British policymakers from the truth that in fighting a 'just' war Britain had lost its position as a Great Power' (ib.). 'Justice' would thus be the weak element of an ill-conceived tactic destined to fail in any event: 'Great Powers are kept going not by gratitude, but by incentives - carrots and sticks - they can deploy to induce other Powers to do what they want' (p. 385).

The literature seems quite sure about the instrumental character of the moral arguments used by 
Keynes with the American negotiators, and employs this factor as a clue to understand some of the outstanding failures of his diplomacy. The 'Fighting for Britain' view favours an interpretation of Keynes as the 'defender of the Empire' (Boughton 2002, p. 12), or at least as 'the Last of the Romans' (De Cecco 1977, p. 18), who instrumentally invokes moral arguments 'in the attempt to construct an international economic environment which would help Britain to adjust to a lesser role' (p. 23). By deliberately choosing to disregard the moral dimension of Keynes's international Weltanschauung, however, this framework fails to heed two key aspects of Keynes's international economics. First, the 'Fighting for Britain' view tends to dismiss the relevance of the dilemmatic nature of decision-making in the international setting, which Keynes conceives as a complex system characterized by organic interdependence and heterogeneity of policies. Second, it neglects the continuity between Keynes's ethics of international economic relations and the anti-utilitarian philosophy underlying his general approach to economics as an instrument to eradicate the 'economic problem', and the precondition to enjoy what he defined as a 'moral life', safeguarding variety while widening (as he wrote in the General Theory) 'the field for the exercise of personal choice'.

\section{MORALS AS A VEIL? FIRST WORLD WAR AND INTER-ALLIED DEBTS}

The Head, since January 1917, of the 'A' Division of the Treasury, responsible for financial relations with the Allies and the United States, Keynes was 'the Treasury official who knew most closely at the time the exact circumstances' in which Inter-Allied debts were incurred (CW 18, p. 104). Keynes was so 'intimate with the details', he wrote at the beginning of World War II, to feel obliged to warn his government that if there was 'a moral to be drawn from last time's experience', it was that 'the arrangements for the credits should be quite different' ( $C W$ 22, p. 26). On the occasion of the first payments of German reparations, Keynes indicated three objections to the view of Inter-Allied debts as 'just like any ordinary commercial debt for goods sold and delivered', namely 'the origin of the debt, the evils which would follow on an attempt to exact them, and the practical impossibility of collection' (CW 18, p. 264). Yet, only the third aspect, which involves purely financial considerations, has been discussed at length in the literature on Keynes's diplomacy. The second and particularly the first ones, related respectively to the prospected outlook of future international trade and the peculiar historical circumstances in which Inter-Allied debts were incurred, have received much less attention.

\section{The origins and nature of Inter-Allied debts}

Inter-Allied debts of World War I originate from the specific 'arrangements for the credits' (CW 22, p. 26) devised for fighting Germany. London had financed the Allies' purchases in Britain, in the empire, and in most neutral countries. Moreover, she had guaranteed and financed Russia's, Italy's (since September 1915) and France's (since May 1916) purchases in the United States, and had acted to support the French exchange (see Burk 1979). Already in October 1916, Keynes had warned that Britain was bound to fall in a condition of 
almost complete financial dependence on the United States. The problem was exacerbated by the need to preserve the exchange rate of sterling vis-à-vis the dollar, which Keynes considered as the financial pivot of the alliance against Germany (Dimsdale 1975, p. 151). Absent American support, he wrote in a secret memorandum of those days, Britain could not 'satisfy successfully the unexampled demand which the efficient prosecution of the war by the alliance as a whole now entails' (CW 16, p. 209). Yet in July 1917, after the declaration of war by the United States, the Secretary of the Treasury McAdoo made clear that 'America's cooperation cannot mean that America can assume the entire burden of financing the war' (in Burk 1979, p. 410), and announced the intention to reduce financial assistance destined to sustain what the United States saw as little more than a 'sentimental exaggeration' (CW 16, p. 240), that is the dollar/sterling exchange rate in New York.

In drafting the Chancellor's reply to McAdoo's cable, Keynes compared the relative financial sacrifices incurred by Britain and the United States during the war. He claimed that 'even since America came into the war the financial assistance afforded to the other allies by the United Kingdom has been more than double the assistance afforded them by the United States, and that the assistance the United Kingdom has afforded these other allies much exceeds the assistance she has herself received from the United States' (CW 16, pp. 246-47). He then criticized America's policy of limiting her assistance to the Allies' purchases within the United States, in recognition of the fact that 'such assistance involves a much less onerous burden than financial assistance abroad' (p. 247). As he was to explain in a future memorandum, 'Before the U.S. came into the war we had made ourselves almost wholly responsible for the foreign financing of the alliance' (p. 279). Despite 'prompt and generous assistance' on the part of the Americans, 'the financial burden continued to fall', even after the latter's entry into the war, 'mainly on our shoulders in the first instance while we threw forward onto the U.S. largely in the form of the assistance we had to ask from them to support the sterling exchange, such part as we were unable to carry ourselves' (p. 280).

In July 1917, Britain's resources were exhausted. Keynes believed that 'unless the United States Government can meet in full our expenses in the United States, including exchange, the whole financial fabric of the alliance will collapse' (CW 16, p. 250). The policy of supporting the sterling/dollar exchange rate was in fact functional to the stability 'not only of the allied exchanges on New York, but also of their exchanges on all neutral countries' (257). The psychological effects of the abandonment of the exchange could have been disastrous: '[t]o point out the depreciation of the German exchanges and the stability of our own has been our favourite form of propaganda in all parts of the world' (p. 222). While venturing 'to appeal to the United States of America for sympathetic consideration in financial discussions' (p. 248), Keynes asked her 'to be the judge of how great a burden she can support. At the present stage of the conflict her resources are greater than ours. She has not only her own pre-war resources', he stressed with force, 'but more than $£ 200$ million additional in actual gold with which the allies have furnished her in the past three years'. America could not 'render a more valuable service' (p. 262) than allowing the Allies more than they could 
afford.

Keynes's words were successful in persuading the American government to concede Britain the financial assistance required to avoid the abandonment of the gold standard. The price to be paid was however higher than expected: as observed by the Treasury representative in Washington, Sir Basil Blackett, Britain was passing from the condition of (the most) 'importune beggar' to the eyes of the Americans to that of 'fellow solvent creditor in the Alliance against Germany' (in Moggridge 1992, p. 276). To Keynes's disappointment, this justified and legitimated the role of 'conduit pipe' (CW 16, p. 280) for American assistance to the alliance as assigned to her by Washington. Keynes was perfectly aware that the United States had a strong interest in reducing Britain to a position of financial dependence, so as to facilitate the shift in world supremacy from London to Washington. He polemically stressed that ' [t]he American public felt a not unnatural willingness to show greater generosity to the allies who relatively were financially weak, and were more inclined in giving assistance to have regard to the sacrifices an ally had suffered than to financial security it could offer' (p. 277), and declared to have 'always understood hitherto that political criticism was to be feared not on the ground that U.K. was receiving too small a share of the U.S. Treasury's advances but that they were receiving too large a share' (pp. 276-77).

Still, he proved wise enough to recognize that the unsatisfactory character of the existing agreement should be attributed to the clash of 'conflicting interests (...) increasingly opposed not only to one another but to the efficient conduct of war' (CW 16, p. 274): the United States had an interest to press the Allies to purchase outside her own borders, whilst it was to the interest of Britain to induce them to place them within America. He warned that '[u]nless considerations of self-interest are put entirely on one side by one party or the other, which is a counsel of perfection, such a system is bound to lead to disputes and suspicions which are unseemly in themselves and detrimental in their consequences to the common cause' (p. 281). Hence the need of a 'mutual understanding', on the part of the 'joint paymasters of the alliance', 'on broad principles of equity and efficient action in view of all relevant circumstances' (p. 274). The United States should have taken over the financing of France's and Italy's needs and proportionally reduced loans to Britain, and allowed London to use the dollar obtained from supplying the Allies (with resources purchased outside America) to meet part of her own American expenditures.

'The business of allied supply and of pooling resources could be conducted with a single eye to efficiency', with 'great moral and political gains'. By eliminating the 'confused currents of self-interest which now darken counsel', the proposal would have raised the respective policies of purchases and supply 'and the advice we tender to one another (...) above the suspicion of being influenced by interested financial motives' (CW 16, p. 284). After both the United States and the Allies had rejected the suggestion, Keynes made no secret of his disappointment: '[i]t almost looks as if [the Americans] took a satisfaction in reducing us to a position of complete financial helplessness and dependence in which the call loan is a noose round our necks and whenever obligations of ours mature in future we shall have to submit any condition they 
may choose to impose' (p. 287).

The effort to understand the non-economic nature of Inter-Allied debts was to Keynes as important as that of revisiting their historical origins. In their response to Keynes's 1928 article The London View of Debt, the editors of New Republic made clear that in the 'American View', war debts were not to be conceived as business investments but had a 'morally binding' (CW 18, p. 298) character and should be clearly distinguished from reparations. Not 'dubious moral attitudes' (ib.) but 'economic circumstances' should provide the rationale for reducing debts and reparation: the fact, that is, that 'they will be either difficult or impossible to pay, and such obligations should not be continued so far into the future. The reason they are so difficult is that they are international obligations not arising out of productive use of human resources. This certainly has an important moral aspect of its own' (pp. 298-99).

Keynes's position is far more complicated, as shown by his correspondence with sociologist John M. Micklin of the Dartmouth College of Hanover on The London View of Debt. His polemical attitude towards the United States Governments after World War I, he explained, was motivated by the American refusal to consider jointly (thus recognizing the linkage between) 'the circumstances out of which the debts arose' and 'the desirability of clearing up the future situation' (CW 18, p. 302). Keynes declared that he laid 'at least as much stress on the first as on the second [reason]. Since my own country has offered to go further than any other in the direction of abating her legal claims, I am at liberty to speak freely. Americans who share your view are prepared, I gather to act to some extent on the second of the above reasons, namely the desirability of clearing up the future; but not on the first of the reasons. Moreover, they are very fond of urging us that if Europe really wants the cash she had better conceal her true feelings about the American position on the first point. I daresay this is true' (ib.).

But the first reason did make much sense to Keynes. In response to a letter from an American correspondent, Mr. Amberson, he explained that 'if America had announced from the first that they were advancing money, not to save civilisation, or any phrase of that kind, but as the best business investment available in the circumstances, no one would have objected to their maintaining the same business attitude subsequently' (CW 18, p. 300). In The London View of Debt, Keynes had observed that it would have been 'very illogical' to regard Inter-Allied debts 'as being in the nature of ordinary investments ... For we often gave assistance in the form of money, precisely because we were less able to assist with men or ships' (CW 9, p. 48). He had pointed out that the Allies were charged for the British guns they had bought and used in the first years of war, not for gunners sent by London when matters got worse. Likewise, the United States was asking Britain to repay materials and munitions received until the American entry into the war, but London was charged nothing for American soldiers helping the Allies to defeat Germany. 'Evidently', he concluded, 'there is not so much logic in a system which causes us to owe money to America, not because at first she was able to help us so much, but because at first she was able to help us, so far at least as manpower was concerned, so little' (ib.). 
Not only logic, but also 'reason (...), justice or common sense' (CW 18, p. 266), Keynes wrote in 1925, were missing in the system. As a 'conduit pipe' for American financial assistance, Britain had lent to the Allies, after America's entry into the war, an amount roughly equal (£750 million) to what she herself had borrowed from the United States ( $£ 850$ million). Two conflicting views of the sums at stake impeded the cancellation of Inter-Allied debts as prompted for by Keynes in The Economic Consequences of the Peace: the American view was that they 'ought to be treated as investments, just like any other business transaction (...) that they should be taken at their face value, that is to say, as bonds due and payable, tempered only by considerations as to the capacity of the debtor to pay and, in practice, by a willingness on the part of the United States to accept a low rate of interest' (CW 9, p. 49). On the contrary, the British view of such debts paid regard 'to their origin and to the circumstances in which they were made' (ib.): they had not been made as business transactions and should not have been treated as such.

In an article written for the Daily Mail on the occasion of the last instalment of the American debt paid by Britain in December 1932, Keynes declared: 'I cannot regard this problem as primarily one of the economic consequences of payment. It is a question of historic justice and of what is right and proper between nations' (CW 18, p. 382). Since there 'never were any profitable assets corresponding to the sums borrowed', he stated, war debts were simply 'a case of pure usury': '[i]t would be a good, not a bad, precedent for the future, to establish a distinction between money lent internationally to foster a war and money lent to build, for example, a railway' (ib.). The concepts of 'profit' and 'interest' simply do not apply to the former case: 'If anyone expects to make a profit out of financing war, there is no harm done if it turns out a bad risk. War loans should never be made except out of sympathy with the cause of the borrower, and the gradual repayment of the sum lent without interest is the most that should be expected. If I lend money to a man to help him expand his business, I am entitled to ask interest. If I lend money to a friend to help him out of a tight place, where there can be no question of his earning a profit, I expect no more than the repayment of my loan' (p. 383). From Britain's 'greater eagerness in a common cause' - her 'wholeheartedness' as 'the sole reason' of her owing money - followed, he observed, that the debt was of a 'non-commercial' nature, and that its measure should be '[t]he replacement cost today of the wheat, cotton, copper, chemicals and munitions which we purchased' at 'profiteering prices' (p. 384) to conduct the war.

\section{The evils of Inter-allied debts and reparations}

Keynes's proposal for an all-round cancellation of Inter-Allied debts dates back to November 1918. It is however in The Economic Consequences of the Peace that Keynes establishes clearly and conclusively the linkage between such debts and German reparations: 'fairness requires', he wrote on presenting his suggestion, that the reduction of reparations to a sustainable amount of resources based on Germany's capacity to pay 'should be accompanied by a readjustment of its apportionment between the Allies' (CW 2, p. 170) through the cancellation of Inter-Allied indebtedness. As we have shown elsewhere (see Caabelli and 
Cedrini 2010b), Keynes conceived Inter-Allied debts forgiveness as an indispensable precondition to solve the problems inherited from the war. In his vision, in fact, the economic organization of the European continent was characterized by organic interdependence: the Treaty of Versailles simply ignored 'the economic solidarity of Europe, and by aiming at the destruction of the economic life of Germany it threaten[ed] the health and prosperity of the Allies themselves' (CW 17, p. 58). Yet, due to the burden of Inter-Allied debts, the Allies were caught in an irresoluble 'dilemma' (CW 2, p. 58). '[D]eeply and inextricably intertwined with their victims by hidden psychic and economic bonds' (p. 2), the Allies could not recede from asking Germany for indemnities which were not only impossible to collect but also potentially devastating for themselves, 'unless one could at the same time point out to them some alternative mode of escape from their troubles' (p. 94).

The way out of the impasse lay exactly in asking the United States and Britain to cancel war debts. Britain should have renounced her share of reparations in cash to the advantage of the Allies, and made 'an appeal to the generosity of the United States' (CW 2, p. 93), whom Keynes believed to be 'greatly at fault', in the negotiations of the Treaty, for 'having no constructive proposals whatever to offer to a suffering and distracted Europe' (p. 94). Though recognizing that this could not 'provide any compelling argument for Americans', Keynes compared the financial sacrifices of the United States and Europe during the war to persuade them that Europe was entitled to ask for such concessions, and that 'an Englishman is not seeking to avoid due sacrifice on his country's part' (p. 175). The appeal to American generosity was simply 'inevitable' (p. 92), not only because the United States 'could better afford to make the sacrifice than Britain and the Allies' (Dimsdale, 1975, p. 157): the generalized situation of conflict involving the Allies and their 'victim' required assistance on the part of actors lying outside the borders of the European impasse, able to reconcile European countries' legitimate claims with the declared aim of a peace of magnanimity, as well as with Germany's (that is the continent's, in Keynes's view) interests in reconstruction and stability. Adopting the model sketched in his 1926 essay against laissez-faire, Keynes was asking Britain and America to act as those public-spirited institutions which only are able to promote the general welfare in social worlds characterized by complexity and interdependence and threatened by conflicts between particular and general interests. The force of the proposal, Keynes claimed, lay in that 'expediency and generosity agree together, and the policy which will best promote immediate friendship between nations will not conflict with the permanent interests of the benefactor' (CW 2, p. 179).

Keynes was convinced of the cruciality of a premise for American generosity: 'the financial problems which were about to exercise Europe could not be solved by greed. The possibility of their cure lay in magnanimity. Europe, if she is to survive her troubles, will need so much magnanimity from America, that she must herself practice it. It is useless for the Allies, hot from stripping Germany and one another, to turn for help to the United States to put the States of Europe, including Germany, on to their feet again' (CW 2, p. 92). In short, commitment on the part of the European countries to reconstruct Europe rather than continue 
war under other forms was both a result of and a necessary condition for the expected American assistance. This amounts to recognizing that the only possibility to escape the troubles of reparations and Inter-Allied debts rested on treating them as parts of a unique question and solve them as such: ' [t]he settlement of the inter-Allied debts is intimately bound up with the reparation settlement. The cancellation of the former would be a ground and an excuse for a sensible conclusion of the latter ... It is nearly impossible, in my opinion, to settle the one question without the other' (p. 277).

Hence the urgency of Inter-Allied debts forgiveness as the precondition for the 'grand scheme for the rehabilitation of Europe' (CW 16, p. 428), that is the 'shared-responsibilities' plan (stopped by the American refusal) of an international loan requiring the whole spectrum of countries involved to participate in the reconstruction. In Keynes's proposal, American assistance to the continent (including Germany's creditors) was conceived as an ignition key allowing a spiral movement of magnanimity to spread along the chain of countries disposed to take part in the 'grand scheme'. Only a gift, acting a 'strange attractor', could provide the starting engine for this movement towards a more balanced international economy. As perfectly expressed by Alvin Gouldner (1973), only a gift as a principle of 'something for nothing' as opposed to the 'something for something' of the norm of market reciprocity, is able to provide both the 'mechanism for stopping vicious cycles of social interaction' (p. 273) and the 'ignition key' that activates reciprocity, so that 'the ongoing cycle of mutual exchange' can start up again (275; see Carabelli and Cedrini 2010b).

\section{On the practical impossibility of collection}

It is only after discussing the nature and evils of Inter-Allied debts that Keynes recognizes the existence of a third motive for their cancellation, namely 'the practical impossibility of collection'. The United States was a 'business country', he wrote in a 1945 memorandum to Chancellor Hugh Dalton during the negotiations of the American loan, 'where it is a moral duty and not merely a self-regarding act to make any money which the traffic will bear and the law allow', so that 'some imitation of a normal banking transaction is necessary if the moral principles of the country are not to be affronted. If the elements of a trade are present, the American way of life requires that at least the appearance of a trade should emerge' (CW 24, p. 548). Therefore, the Americans should have been sensible to what he named, in an article of 1921, 'the foreign trade argument' (CW 17, p. 277).

In his memorandum 'The Treatment of Inter-Ally Debt Arising Out of the War' of March 1919, Keynes had warned that '[i]f the loans are to be met, a serious obstacle will exist to future trade relations between the Allies' (CW 16, p. 424). Britain should necessarily stimulate exports to the United States and imports from the Allies, bitterly opposing trade flows in the opposite direction: 'trade must be mainly one way' (ib.). Those between the post-war world and the pre-war gold standard order were 'false analogies' ( $\mathrm{CW}$ 18, p. 40): Europe, now a debtor, could not rely, in the future, on American loans with a self-liquidating character. The practice of foreign investment was 'only suited to particular circumstances' wherein an 'old 
country can (...) develop a new one at a time when the latter could not possibly do so with its own resources alone', so that 'the arrangement may be mutually advantageous; and out of abundant profits the lender may hope to be repaid' (CW 17, p. 274). This time there was 'no natural increase, no real sinking fund, out of which [he] can be repaid', so that '[t]he unwillingness of American investors to buy European bonds is founded in common sense' (ib.).

But this implies that '[i]f [...] the United States were to exact payment of the Allied debts, the position would be intolerable. If she persevered to the bitter end, scrapped her export industries, and diverted to other uses the capital now employed in them, and if the former European associates decided to meet their obligations at whatever cost to themselves, it is not impossible that the final result might be to America's material interest. But the project is utterly chimerical. It will not happen. Nothing is more certain than that America will pursue such a policy to the bitter end; she will abandon it as soon as she experiences its first consequences. Nor, if she did, would the Allies pay the money' (CW 17, p. 276). The decisive argument for debt cancellation on the part of the United States, therefore, was 'the unlikelihood of permanence in the exaction of the debts [...] because of the great difficulty of the problem which the United States has before her in any case in balancing her commercial account with the Old World' (CW 3, p. 110).

In Keynes's vision, the American position was 'exactly parallel to that of German reparation' (CW 17, p. 276): 'America will not see through the repayment of Allied debt any more than the Allies will see through the collection of their present reparations demands' (p. 277). In replying to Mr. Amberson on the moral arguments expressed in A London View of War Debts in favour of the cancellation of such debts, Keynes drew on this parallel to suggest that Inter-Allied debts and reparations would have produced similar, dreadful effects on future creditors-debtors relationships. Significantly, he clarified that he did not 'consider that America had any 'obligation' to do anything whatever ... I do not suggest for a moment that any mitigation should be offered by America unconditionally' (CW 18, p. 300). Yet America, in his words, carried 'a share of responsibility which is not negligible for securing a just settlement' of reparations (ib.).

For Keynes, the American view itself of Inter-Allied indebtedness, that is the belief that it could be settled on commercial bases, was a logical mistake grounded on false analogies. Not only had war so shaken the European system as to reveal the 'sandy and false foundation' (CW 2, p. 1) of its economic organization, but the whole ensemble of debt relationships linking the Old World with the New in the pre-1914 order was 'fragile; and it has only survived because its burden on the paying countries has not so far been oppressive, because this burden is represented by real assets and is bound up with the property system generally, and because the sums already lent are not unduly large in relation to those which it is still hoped to borrow'. The problem is that bankers 'are disposed to believe ... by analogy with it, that a comparable system between Governments, on a far vaster and definitely oppressive scale, represented by no real assets, and less closely associated with the property system, is natural and reasonable and in conformity with human nature' (pp. 178-79). 
On the contrary, 'the whole position' of Inter-Allied debts was 'in the highest degree artificial, misleading, and vexatious' (CW 2, p. 178). 'The existence of the great war debts', Keynes argued, thereby inaugurating a line of argument based on the parallel between internal and external debt, 'is a menace to financial stability everywhere. There is no European country in which repudiation may not soon become an important political issue. In the case of internal debt, however, there are interested parties on both sides, and the question is one of the internal distribution of wealth. With external debts this is not so, and the creditor nations may soon find their interest inconveniently bound up with the maintenance of a particular type of government or economic organization in the debtor countries. Entangling alliances or entangling leagues are nothing to the entanglements of cash owing' (p. 177). True, the evils of internal debts could be reduced by a capital levy, but 'the continuance on a huge scale of indebtedness between Governments has special dangers of its own' (p. 178). Inter-Allied debts would have imposed 'a crushing burden' on European Allies, who might then be expected to 'make constant attempts to evade or escape payments, and these attempts will be a constant source of international friction and ill-will for many years to come. A debtor nation does not love its creditor' (p. 177).

\section{ANTI-SOCIAL ACTS AND POETIC JUSTICE: THE INTERWAR PERIOD}

In a 1925 article on Inter-Allied indebtedness, Keynes remarked that both such debts and the 'theoretical liabilities of Germany under the treaty of Versailles' were both to be considered as 'a matter of politics and not of law or contract' (CW 18, p. 264). Seven years later, on the Daily Mail, he introduced limits to the cogency of the 'sanctity of contract' (p. 384) even for liabilities which do not derive from military confrontation. The 'sanctity of contract', he pointed out in general terms, is not 'an immutable law of nature' and cannot be preserved 'except by the reasonableness of the creditor' (ib.). Britain lacked gold resources to repay the WWI American debt; she was therefore forced to 'buy less' from America and to make the latter an 'offer to sell more', which the Americans respectively saw, in Keynes's words, as 'a reprisal' and 'an injury' (p. 385). Yet he maintained that '[d]ebtors are only honourable in countries where creditors are reasonable. If creditors stand on the letter of the law, debtors can usually show them how little the law avails. Internationally, contract has nothing to support it except the self-respect and self-interest of the debtor. A loan, the claims of which are supported by neither, will not be paid for long' (p. 384). Keynes claimed that Britain had always acted on such lines: '[t]hough not at first, yet in the coolness of time we have shown that we are still reasonable, and that we practice what we preach' (ib.). He then went so far as to define it a specific 'duty of the creditor not to frustrate payment' (p. 385): the debtor cannot be asked to renounce its 'self-respect and self-interest' - he added, making a clear distinction between the latter and 'narrow calculations of financial self-interest' on the part of the creditor -, which were 'powerful motives' with Britain to 'do our utmost for a friendly and fair settlement' (ib.).

International debt/credit relationships occupy a central position in Keynes's whole work as an 
international economist engaged in the attempt to construct a 'sounder political economy between all nations' (CW 25, p. 43). During the interwar period, his attention is constantly posed on what he defined, thereby establishing a tradition in this regard, as the 'rules of the game' (CW 20, p. 599) of the gold standard, and the explicit aim of his work as an international negotiator in the years of World War II was to produce a revolution in the management of the relationships between debtor and creditor countries. The harmonious traits of what Keynes considered as a 'lost paradise' (Dimand 2006, p. 175), that is the pre-war regime centered on Britain's leadership and a mutually advantageous partnership between the old world and the new, were to reappear at the beginning of the Forties in the plan for the International Clearing Union (ICU). There Keynes points at the pre-war regime as the only recent historical experience of intended and successful struggle with the 'secular international problem ... of maintaining equilibrium in the balance of payments of between countries' (CW 25, p. 21).

The system worked because 'special influences were present which largely removed the burden of pressure, or reversed its direction, as between the debtor country and the creditor or the world at large ... in the Victorian age the peculiar organisation in London and to a less extent in Paris, the two main creditor centres, by which a flow of gold immediately translated itself, not in the first instance into a change in prices and wages, but into a change in the volume of the foreign investment by the creditors, caused the burden to be carried by stronger shoulders' (CW 25, p. 30). Although in the first phase after the war, funds continued to flow from creditor to debtor countries, these were mostly speculative flows, that is they were not destined to the development of new resources. Then 'complete degeneration set in and capital funds flowed from countries of which the balance of trade was adverse into countries where it was favourable' (p. 31). Hence Keynes's proposal for shifting part of the adjustment burden on creditor countries and his position in favour of capital controls.

Already in his 1929 lectures to the Geneva School of International Studies, Keynes had defined foreign investment as 'a process by which rich countries spread the proceeds of their wealth over the world, and thus is internationally desirable' (in Fleming 2000, p. 142). Yet, he claimed, it could not be supported 'on nationalist grounds' (ib.) any longer, since Britain was now a debtor country (which explains why Keynes had reversed the position he had held in his 1910 articles on the virtues of Britain's foreing lending) suffering from high efficiency wages and lacking funds and opportunities for domestic investments. In the absence of specific arrangements with her creditors, Britain was therefore compelled to a decade of deflation. Gold concentration in creditor countries, the United States and France, prevented a smooth international adjustment driven by raising prices in debtor countries. Although the total quantity of gold was sufficient, its distribution was 'very unequal' (p. 150), Keynes remarked on proposing to use the newborn Bank for International Settlement as a supranational authority gradually replacing gold with an international currency. 
In his 1931 Chicago lectures, he pointed out that at the end of the Twenties, when everyone was thinking about the return to gold as the means to prosperity, 'the United States was a free purchaser of all kinds of foreign bonds, good, bad, and indifferent - a free lender for investment purposes, that is to say, to the rest of the world. To an important extent the United States was acting, in this generous foreign-loan policy, as a conduit pipe for the savings of the more cautious Europeans, who had less confidence in their own prosperity than America had' ( $C W$ 13, p. 345). Then came dear money, the drain of foreign gold resources, the credit crunch with a lowered willingness to buy foreign bonds and finally the speculative boom of the stock exchange. 'For the last two years', he explained in an article on the 'Great Slump of 1930', 'two out of the three principal creditor nations of the world, namely, France and the United States, have largely withdrawn their resources from the international market for long-term loans' (CW 9, p. 132). On the eve of the 1931 sterling crisis, Keynes explicitly attacked them: '[i]t cannot and will not work the international gold standard if the other creditor countries do not play the rules of the game" (CW 20, p. 599). 'The whole world is heartily sick of the selfishness and folly with which the international gold standard is being worked. Instead of being a means of facilitating international trade, the gold standard has become a curse laid upon the economic life of the world' (p. 600).

America and France were not lending 'their surplus balance on international account as Great Britain used to do in the past' (CW 20, p. 600). 'France', Keynes argued, 'appears to have employed virtually the whole of her international surplus during the last three or four years in the purchase of gold and short-term liquid claims instead of embarking on long-term investment abroad. The attitude towards long-term foreign investments of investors in the United States has varied but has been generally unfavourable, except in period of boom when American issuing houses have lost their heads' (ib.). To describe 'the game from the point of view of the debtor countries' (p. 601), Keynes quoted a passage of the report of the Macmillan Committee, after pointing out that the only use of gold reserve was 'as a medium for meeting a deficit on the balance of international payments until steps have been taken to bring it again to equilibrium': '[i]t is usually beyond [debtor countries'] power to adjust their balance of payments so rapidly and completely as to permit a complete cessation of borrowing: yet, in so far as they export gold, their credit as borrowers suffers. Thus, having lost their gold and not being able to borrow, they are forced off the gold standard' (ib.). Keynes bitterly concluded that '[w]e must make it plain to our friends on the gold standard that, if they refuse to play the game according to the rules, this is not to be made a compelling reason for reducing the standard of life in this country for a generation' (ib.).

Only a reasonable distribution of loans for capital development among the three financial centres, he had argued in his Chicago lectures, and accrued absorption of foreign loans on the part of New York and Paris, could produce the required 'large new creation of international credit which would tend to support commodity prices and stimulate international trade' (CW 20, p. 347). After the sterling crisis, Keynes explicitly called for a gold conference. His suggestion might have been a 'cover, for he had become 
convinced of the inevitability of devaluation in the near future' (Moggridge 1992, p. 526). Having in mind the interests of the system as a whole, Keynes described domestic measures to improve the balance of trade as definitely second-best policies, which 'not only do nothing helpful to the outside world but may actually be injurious' (CW 20, pp. 613-14) and make it 'still more difficult for debtor countries to meet their obligations' (p. 614). Yet he saw in sterling's devaluation, le fait accompli, a chance to conciliate national and global interests, as long as this measure had an international, public-spirited nature, and could serve as a cure for the international disease of an interdependent economic world populated by countries unwilling (creditors) or unable (debtors) to follow the rules of the game.

Keynes's conference to the International Economic Society of Hamburg (January 8, 1932) focused on the international 'competitive struggle for liquidity' (CW 21, p. 40), which he described as 'an extreme example of the disharmony of general and particular interest' (p. 52). Each government was trying 'to make its international balance sheet more liquid by restricting imports and stimulating exports by every possible means, the success of each one in this direction meaning the defeat of someone else. Moreover every country tries to stop capital development within its own borders for fear of the effect on its international balance. Yet it will only be successful in its objects in so far as its progress towards negation is greater than that of its neighbours' (p. 40). The problem was 'mainly international' and required an 'international cure': 'the leadership of Great Britain'. She only could, to the 'general advantage' (p. 57), 'resume the vacant financial leadership of the world, which no one else has the experience or the public spirit to occupy, speaking out of acknowledged strength and not out of weakness' (CW 9, pp. 235-36).

Once regained her power of initiative, Britain should have used it 'without hesitation or delay for expanding purchasing power ourselves and for helping others to expand. We must set the example' (CW 21, p. 62). He proudly claimed that 'the possession of a large amount of gold will be no handicap later on when we are considering conversion schemes and large-scale international financial assistance. The gold will be more fruitful in our hands than in France or the United States' (p. 81). After sterling's devaluation, he wrote in his article The Future of the World of September 1931, Britain could finally play 'the part of a reasonable creditor who moderates his claim in view of so great a change in the situation as the recent catastrophic fall in commodity prices' (CW 9, p. 247). Countries following Britain's example would have benefited of higher prices, but - the passage is worth quoting in full - 'none of us will secure a competitive advantage at the expenses of the others. Thus the competitive disadvantage will be concentrated on those few countries which remain in the gold standard. On these will fall the curse of Midas. As a result of their unwillingness to exchange their exports except for gold their trade exports will dry up and disappear until they no longer have any either a favourable trade balance or foreign deposits to repatriate. This means in the main France and the United States. Their loss of export trade will be an inevitable, a predictable, outcome of their action. These countries largely for reasons resulting from the war and the war settlements, are owed much money by the rest of the world. They erect tariff barriers which prevent the payment of these sums in good. They 
are unwilling to lend it. They have already taken nearly all the available surplus gold in the whole world. There remained, in logic, only one way by which the rest of the world could maintain its solvency and selfrespect; namely, to cease purchasing these countries' exports. So long as the gold standard is preserved which means that the prices of international commodities must be much the same everywhere - this involved a competitive campaign of deflation, each of us trying to get our prices down faster than the others, a campaign which had intensified unemployment and business losses to unendurable pitch' (p. 248).

In Hamburg, Keynes had gone so far as to define '[t]he undermining of the competitive position of the export industries of [the] gold countries' as a 'response to their own request; - or, at any rate a case of poetic justice' (CW 21, p. 45). By '[e]xercising deflationary pressure on the rest of the world by having a net creditor position which causes them to draw gold' (p. 44), France and the United States were directly responsible for the 'cessation of the international lending which had been off-setting the disequilibrium of the balances of payment between countries which War debts and tariffs would have already produced otherwise' (p. 212). They could therefore be assimilated to 'an individual or an institution or a public body, which voluntarily and unnecessarily curtails or postpones expenditure which is admittedly useful, [thus] performing an anti-social act' (p. 53), whereas it was 'a high social duty today for everyone to use his influence, whatever it may be, in private and in public, in favour of every kind of expansion and expenditure, which is financially possible to those who incur in it, and which in better terms would be generally admitted to be legitimate and useful' (p. 60). Creditor countries, on the contrary, believed '[t]heir own accumulations [to be] the reward of virtue, and the losses which the rest of us have suffered ... the penalty of imprudence' (ib.). In his Reflections on the Sterling Exchange of April 1932, Keynes exposed a 'philosophic reflection on these matters' which included the telling of the story of 'a Senator from the Middle West who cried in a loud voice to Europe: We do not want your goods. We will not have your bonds. We have already got your gold. What we want is your money'. The Senator may be mythical, but there still remained a logical alternative left to Europe which he overlooked, namely, for the rest of the world to get on as best it can without buying the exports of those countries which have an unbalanced creditor position' (p. 78).

Keynes knew that 'the solution to which we have been driven' was 'unsatisfactory for everyone', since the world needed a trade recovery in the united States, but was doubtful about the possibility that the gold standard countries could 'learn the terms, which must needs be strict, on which we should be prepared to re-enter the system of a drastically reformed gold standard' (CW 9, p. 249), or that they could provide 'direct relief of financial tension between nations' (CW 21, p. 214). As he remarked on occasion of the 1933 World Economic Conference, '[t]his kind of philanthropy will never be large enough in scale; the division of the burden will never be rightly agreed; nor will the division of the proceeds', all the more so since '[f]or several years we have been trying to buy ourselves out of the mess by such means, and our attempts are a proved failure. One chance there was - at Paris in 1919, when a loan of reconstruction might have been part 
of a general plan for the world's appeasement; but that we blindly rejected' (p. 215).

\section{V. $\quad$ CREDITORS, DEBTORS AND RENTIERS}

Reading the interwar period 'in terms of Keynes's theory', Skidelsky claims that 'the much greater uncertainty arising from unsettled conditions after the First World War had brought about a big increase in liquidity preference, whose international expression was the hoarding rather than spending of reserves' (2009, p. 180). The hypothesis of continuity between Keynes's analysis of individual behaviour in domestic economies and his view of political economy between countries in the international setting is quite reasonable. According to De Cecco (2001), in the 'Historical Illustrations' of A Treatise on Money Keynes had come to construct a vision of economic history as an eternal conflict between debtors and creditors, a vision later embodied in the theory of liquidity preference. In the Treatise, debtors and creditors correspond respectively to 'entrepreneurs engaged in profits-seeking activities, demiurges of social welfare, and rentiers whose unique interest is to find the most liquid assets for holding their financial resources, so as to be able to stop hoarding and start lending as rapidly as possible when the occasion comes' (p. 379; our translation). But the whole economic analysis of Keynes 'largely consists of working out the consequences for the whole economic system of the interactions of these three interest groups, or classes [entrepreneurs, workers and rentiers], and in particular the two most important ones, entrepreneurs and financial rentiers' (De Cecco 1990, p. 182).

In The End of Laissez-Faire, Keynes holds that '[t]he world is not so governed (...) that private and social interest always coincide .... It is not a correct deduction from the principles of economics that enlightened self-interest always operates in the public interest. Nor is it true that self-interest generally is enlightened ... Experience does not show that individuals, when they make up a social unit, are always less clear-sighted than whey they act separately' (CW 9, pp. 287-88). A major reason why private and social interest may not coincide is to be found in that society is made of different socioeconomic classes - the investing class, the business class, and the earning class, according to the scheme exposed in The Monetary Reform - and that 'such a division corresponds to a social cleavage and an actual divergence of interest' ( $C W$ 4, p. 4).

Individual capitalism before the war, Keynes wrote in The Economic Consequences of the Peace, was based on a certain 'psychology of society', which was 'so framed as to throw a great part of the increased income into the control of the class least likely to consume it' and, as a consequence, to make it possible 'to secure the maximum accumulation of capital' (CW 2, p. 11). The highly inequal distribution of wealth which resulted was thus functional to the general interest, since the rich 'held narrower ends in prospects' (ib.). But the system was founded on 'double bluff': both the labouring and the capitalist classes, whether voluntarily or not, were subject to the Puritan 'duty of saving', to a principle of 'non-consumption of the cake' (p. 12).

Disclosing the 'possibility of consumption to all and the vanity of abstinence to many' (p. 13), the war 
revealed the bluff, and income inequality became a major social problem. Keynes believed the passing from old-style proprietary capitalism to the dominance of big corporations and the separation between ownership and management to be responsible for the emergence of a new group of 'financial investors' whose interests are 'partly divergent' with respect to those of 'business men' (CW 4, p. 5), that is 'the active and constructive element in the whole capitalist society' (CW 2, p. 149).

Hence the occurrence of two dichotomies in capitalist institutions (see Elliott and Jensen 1997): that between 'industry' and 'finance' and the one between 'speculation' and 'enterprise', dychotomies used by Keynes in the General Theory to support the 'three major components of his argumentarium: the demand for and supply of money, and thereby the rate of interest; the expected rate of profit and thereby the volume of investment; and the propensity to consume' (ib., p. 107). As to the first, speculative demand for money in Keynes's theory is typical of rentiers, whereas industry requires money for motives of transactions and precaution. As to the second, entrepreneurs in former times 'embarked on business as a way of life, not really relying on a precise calculation of prospective profits', and investment decisions were 'largely irrevocable, not only for the community as a whole, but also for the individual' (CW 7, pp. 150-51). With the advent of purely financial speculation, conversely, the capital development of the country is transformed into the 'byproduct of the activities of a casino' (p. 159). Finally, the consumption decisions of a wealth-owner are based on 'unforeseen changes in the money value of the money-value of its wealth' (p. 93), which often results in the working class suffering from involuntary unemployment.

In Keynes's economics, '[r]entiers' basic craving for satisfaction' materializes 'in a desire to obtain financial gains, not through production, but through the speculative demand for or placement of liquid funds' (Elliott and Jensen 1997, p. 110). In Keynes's liquidity preference theory, the reason why 'anyone outside a lunatic asylum [should] wish to use money as a store of wealth' (CW 14, pp. 115-16) is that 'the possession of actual money lulls our disquietude, and the premium which we require to make us part with money is the measure of our disquietude' (p. 116). Occupied with 'foreseeing changes in the conventional basis of valuation a short time ahead of the general public' (CW 7, p. 154), financial investors and speculators operating in a context of 'dimmed' animal spirits and pessimism produce a state of affairs which induces rentiers to 'prefer the control of liquid cash to parting with it in exchange for a debt on the terms indicated by the market rate of interest' (pp. 205-206). Rentiers may thus be willing to lend uniquely at a rate which exceeds the marginal efficiency of capital, thereby discouraging entrepreneurs from 'calling 'to the aid of their enterprises' the wealth of the rentiers' (Elliott and Jensen 1997, p. 112).

Elliott and Jensen identify three main criticisms of the rentier-like attitude in Keynes's economics. First (for convenience, the 'demand for money' criticism), by controlling the speculative demand for money and, as a result, by affecting the interest rate, rentiers 'are in a strategic position to dominate and to take advantage of entrepreneurs and workers' (p. 113). An increase in the demand for money produced by a larger liquidity premium between money and goods necessarily produces a decrease in the demand for 
goods and labour: 'in short, the demand for money is not a demand for goods or to employ labour' (ib.). A second criticism ('dead hand') is related to Keynes's preference for inflation over deflation, which rests on the view that 'it is worse, in an impoverished world, to provoke unemployment than to disappoint the rentier' (CW 4, p. 36). Inflation decreases the burden of debt and 'emancipates' debtors 'from the dead hand [of] the past' (p. 9), as Keynes explained in The Monetary Reform. Finally, Keynes sees literally no function at all in the rentiers' activity ('functionless investor'). This rests solely on the scarcity of capital, which Keynes considers not a natural feature of a market economy but a purely artificial one (see Carabelli and De Vecchi 1999). Contrary to natural resources, in fact, the use of capital does not bring about 'a genuine sacrifice which could only be called forth by the offer of a reward in the shape of interest' (CW 7, p. 376). The scarcity of capital is rather the 'reflection in economic terms of the fact that in a market economy the motivation of money for money's sake has, over time, reached a particular high level in the scale of values' (Carabelli and De Vecchi 1999, p. 281).

The two dichotomies cited above and Keynes's 'mixture of scorn and hostility for the rentiers' (Meltzer 1989, p. 5) are not extraneous to the latter's portrayal of the international society as the historically contingent result of a perpetual struggle between debtor and creditor countries. In particular, both in the aftermath of World War I and in the interwar period, Keynes attributes to creditor countries those same faults he ascribes to rentiers in his analysis of domestic capitalism. The central message of The Economic Consequences of the Peace is that Inter-Allied debts could not but impose their 'crashing burden' on the fragile economic organisation of a distressed and ruined Europe, all the more so in a context of structurally unbalanced relationships between the continent and America - so that, Keynes wrote in 1921, 'the restoration of some equilibrium must be a chief problem of the near future, politically as well as economically' (CW 17, p. 273). Neither Germany - 'nations are not authorised, by religion or by natural morals, to visit on the children of their enemies the misdoings of parents or of rulers' (CW 2, p. 222) - nor Europe - she 'must depend in the long run on her own daily labor and not on the largesse of America; but, on the other hand, she will not pinch herself in order that the fruit of her daily labor may go elsewhere' (CW 16, p. 427) - will 'die quietly' (CW 2, p. 144) under the 'dead hand' of the past.

The rentier-like attitude of the United States in particular is easily detectable, as seen, in Keynes's criticism of the American view of debts as business investments. In an article of August 1923, he calculated the opportunity cost of Britain's American debt and emphasized the cost of thinking in terms of 'demand for money' and 'demand for goods or to employ labour': 'We shall be paying to the United States each year for sixty years a sum equivalent to two-thirds the cost of our Navy, nearly equal to the State expenditure on education, more than the total burden of our pre-war debt, more than the total profits of the whole of our mercantile marine and the whole of our mines together. With these sums we could endow and splendidly house every month for sixty years one university, one hospital, one institute of research, etcetera, etcetera. With an equal sacrifice over an equal period we could abolish slums and rehouse in comfort the half of our 
population which is now inadequately sheltered' (CW 18, p. 194).

Keynes's criticism of the international rentier as a functionless investor is implicit in the antiutilitarian philosophy which underlies his economic diplomacy. In his methodological manifesto - the exchange with Roy Harrod concerning the latter's Scope and Method in Economics - Keynes defines economics as 'a branch of logic, a way of thinking ... in terms of models joined to the art of choosing models which are relevant to the contemporary world' (CW 14, p. 296). For Keynes, the object of economic analysis is in fact 'not to provide a machine, or method of blind manipulation, which will furnish an infallible answer, but to provide ourselves with an organised and orderly method of thinking out particular problems' (CW 7, p. 297). In short, Keynes believes economics to be not a natural science relying on positivistic methods, but a method that helps economists to draw logically correct conclusions, that is to avoid logical fallacies in reasoning such as the fallacy of composition. Economics is even 'compelled' to be a branch of logic rather than a natural science à la Robbins, since 'the material which it is applied to is, in too many respects, not homogeneous through time' (CW 14, p. 296). As it is the case with probability (the Treatise on Probability is de facto Keynes's 'essay on method': see Carabelli 1988), the economic material possesses attributes of complexity which should compel the economist to reject the blind application of mathematics and statistics, as well as of their assumptions of homogeneity, atomism and independence, to an object that is essentially vague and indeterminate, not homogeneous, not divisible in homogeneous independent parts, non finite, and characterised by organic interdependence. Moreover, Keynes emphasizes that economics is a 'moral science' which employs 'introspection and judgements of value' (CW 14, p. 297), and has to deal with changing factors as 'motives, expectations, psychological uncertainties' (ib.), that is 'with human beings in their social environment' (Marchionatti 2010, p. 131).

It should not comes as a surprise, therefore, that 'economics and ethics are close companions in Keynes's intellectual framework' (O'Donnell 1989, p. 164). But to Keynes, 'the role of economics was that of service to the higher discipline of ethics' (ib.). In ethics, Keynes distinguishes between 'speculative ethics', that is 'one's attitude towards oneself and the ultimate', and 'practical ethics', or 'one's attitude towards the outside world and the intermediate' (CW 10, p. 436); '[t]he first is the rational analysis of the ultimate aims of human action, and the second covers politics and economics, which, being at the service of ethics, analyse and discuss ways of building an "ethically rational society" (Carabelli and De Vecchi 1999, p. 279). Speculative ethics concerns ultimate ends and values of human action whose nature is intrinsically good: following George Edward Moore, the author of Principia Ethica, Keynes stresses that some general and abstract moral ends such as love, friendship, beauty, truth, and knowledge, are universally intrinsically desirable and ought to be pursued in any time and circumstance. Practical ethics is the domain of politics and economics, and include probability, uncertainty and action as well. Since practical ethics is directed towards the construction of an ethically rational society, the ends of economics and politics are neither absolute nor universally valid: rather, they act as necessary prerequisites for social progress and the 
attainment of increasingly higher levels of goodness. Practical ethics, says Keynes in a youth paper entitled Miscellanea Ethica (1905), is concerned 'with conduct: it would investigate the difficult questions of the probable grounds of actions, and the curious connection between 'probable' and 'ought': and it would endeavour to formulate or rather to investigate existing general maxims, bearing in mind their strict relativity to particular circumstances' (ib.).

Keynes's ethics is, in line with Aristotle, an ethics of virtues (see Helburn 1992; Carabelli 1998), which is concerned with the whole conduct of human life: not only with single actions and related moral duties, but with the whole texture of the character from which the act flows, with motives and intentions, and even reactive feelings and emotions. Keynes believes, in agreement with ancient ethics, that the good life has necessary material and institutional necessary conditions: human flourishing requires material prerequisites. The task of political economy as a moral science is therefore to him precisely to supply these material conditions as necessary preconditions for the good and happy life (see Carabelli and Cedrini 2009).

Keynes's philosophy was fully anti-utilitarian. In his 1938 autobiographical sketch My Early Beliefs, he defined 'the Benthamite tradition ... as the worm which has been gnawing at the insides of modern civilisation and is responsible for moral decay' (CW 10, p. 445). Already in December 1925, Keynes had written some notes on the love for money attacking the 'test of money measurement [which] constantly tends to widen the area where we weigh concrete goods against abstract money', the 'sanctification of saving' and the tendency to 'sacrifice the present to the future' without being sure that the exchange is worth while (in Skidelsky 1992, p. 21). In the famous essay The Economic Possibilities for Our Grandchildren, Keynes argues that 'the economic problem' - 'the problem of want and poverty and the economic struggle between classes and nations' (CW 9, p. xvii) - 'may be solved, or be at least within sight of solution, within a hundred years', so that it would be wrong to define it as 'the permanent problem of the human race' (p. 326). The essay is a violent criticism of the 'old Adam' and human 'purposiveness' (p. 329), that is our being 'more concerned with the remote future results of our actions than with their own quality or their immediate effects on our own environment' (pp. 329-20). With the end of the economic problem - 'the western world already has the resources and the technique, if we could create the organisation to use them, capable of reducing the economic problem, which now absorbs our moral and material energies, to a position of secondary importance' (p. xvii)- man will be 'less preoccupied with accumulation of wealth' (p. 331) and be free to deal with his 'real problems - the problems of life and of human relations, of creation and behaviour and religion' (CW IX: xvii). Once material wealth is 'no longer of high social importance, there will be great changes in the code of morals ... We shall be able to afford to dare to assess the money-motive at its true value. The love of money as a possession - as distinguished from the love of money as a means to the enjoyments and realities of life - will be recognised for what it is, a somewhat disgusting morbidity, one of those semicriminal, semipathological propensities which one hands over with a shudder to the specialists in mental disease'. 'We shall', he concluded, 'once more value ends above means and prefer the good to the useful' (ib.). 
As seen, Keynes treated war debts as 'a case of pure usury', and saw the 'common cause' against Germany, in Mooreian terms, as an ultimate good. Friends should not treat each other instrumentally, since friendship requires fairness of treatment. But the 'functionless investor', who demands money rather than goods, is also the main issue at stake in Keynes's criticism of creditor countries in the interwar period, as it is immediately evident from the use of the allegory of 'a Senator from the Middle West, who cried in a loud voice to Europe: 'We do not want your goods. We will not have your bonds. We have already got your gold. What we want is your money" (CW 21, p. 78). The analogy between domestic and international rentiers was explicit and complete: Keynes directly attributed the economic catastrophe of the Thirties, which he described as an example of extreme 'disharmony of general and particular interest' of the kind of those engendered by the conflict between productive and unproductive classes, to the 'anti-social' behaviour of international rentiers. 'What the traditional view called 'savings' Keynes saw as 'hoarding" (Dillard 1946, p. 216), also at the international level. The rentier had completely lost her/his function: international disequilibrium was due to the creditors' unwillingness to lend their surplus, 'as Great Britain used to do in the past', to the benefit of global multilateralism.

Moreover, by pointing at the 'competitive struggle for liquidity', Keynes laid down the foundations of the General Theory. In A Treatise on Money, Keynes's vision of economic history as a permanent conflict between debtors and creditors is supplemented by the awareness of a true 'dilemma of the international system', that is the double need 'to preserve the advantages of the stability of the local currencies of the various members of the system in terms of the international standard, and to preserve at the same time an adequate local autonomy for each member over its domestic rate of interest and its volume of foreign lending' (CW 6, p. 272). In short, Keynes sees international discipline (as regards exchange rates and capital movements), one the one side, and domestic autonomy (as regards policy to attain and maintain full employment), on the other, as two competing interests potentially destined to clash one against the other, as the Thirties were to show. The 'case of poetic justice' against irresponsible creditor countries had brought protectionism to the attention of Keynes, who had come to invoke self-sufficiency and the nationalisation of finance, to the extent that the only chapter of The General Theory explicitly dealing with international economic relations includes a rediscovery of mercantilism.

In that chapter, Keynes indirectly shows where to search for a national behaviour which can lie in harmony with the interests of the system (see Moggridge 1986), thereby solving the dilemma of the international system. Keynes stated that in the absence of alternative methods of controlling the national inducement to invest, a country would be right in attempting to reach and maintain a favourable balance of trade, since the latter is the only direct means available for increasing foreign investment and the only indirect means of reducing the domestic interest rate (which is otherwise governed by liquidity preference and money supply). Significantly, Keynes used Heckscher's expression 'fear of goods' (CW 7, p. 347), which much resembles the rentier's demand for money rather than for goods. He also described the virtues of 
mercantilists' attempt to get rid of an unwelcome surplus of goods - which might produce unemployment and to increase the domestic stock of money with a view to reducing interest rates. To advocate laissez-faire in a gold standard regime is patently absurd, Keynes asserted: for if the rate of interest and the money supply are primarily determined by the balance of payments, 'there is no orthodox means open to the authorities for countering unemployment at home except by struggling for an export surplus and an import of monetary metal at the expense of their neighbour' (pp. 348-49).

Yet, if 'domestic prosperity [is] directly dependent on a competitive pursuit of markets and a competitive appetite for the precious metals' (CW 7, p. 349) and gold supplies are insufficiently abundant, international trade is destined to become what it had been in the early Thirties, that is 'a desperate expedient to maintain employment at home by forcing sales on foreign markets and restricting purchases, which, if successful, will merely shift the problem of unemployment to the neighbour which is worsted in the struggle' (pp. 382-83). True, in the General Theory Keynes looks at international economic relations from the point of view of a single country engaged in the competitive struggle for liquidity, to the extent that the only concrete solution to the impasse is seen, once again, in Britain's playing the role of a 'reasonable creditor', one who neither frustrates payment nor sacrifices the debtor's self-respect and self-interest to narrow calculations of financial self-interest. A creditor, in other words, who feels less fear of goods than the two international rentiers and promises to 'secure for [her]self no larger a share of the stock of the precious metals than is fair and reasonable' (p. 338), so as to 'leave room for the international division of labour and for international lending in appropriate conditions' (p. 382). Yet the adjustment burden would have fallen on the system's irresponsible creditors; though an act of poetic justice, Keynes knew that ' $[\mathrm{t}]$ he world will never be prosperous without a trade recovery in the United States. Peace and confidence and a harmonious economic equilibrium for all the closely interrelated countries of the globe is the only goal worth aiming at' (CW 9, p. 249).

\section{EUTHANASIA OF RENTIER COUNTRIES: THE INTERNATIONAL CLEARING UNION}

The story of the planning of Keynes's schemes for global reform intertwines with that of his attempts to secure American financial assistance to the new alliance against Germany. It is in a 1939 memorandum destined (but never sent) to President Roosevelt, that Keynes endeavours to establish a principle of 'common cause' for the new financial arrangements between the Allies. His suggestion to the 'Four empires' was to establish a 'joint purchasing board for the proper regulation of prices and profits' (CW 22, p. 26) based on a structure of interest-free credits; America's credits should not be repayable, he added, for they 'should constitute a part of the contribution of the United States to the post-war reconstruction of Europe': '[t]his time it must be clear from the beginning that the indemnity is paid by the victor to the vanquished' (p. 27). In asking the United States to support such a plan of 'unprecedented generosity' (p. 28) - words Keynes directly borrowed, as seen, from the 'Economic Consequences of the Peace' - and to provide further gold resources as 
a 'measure of responsibility ... for the terms of peace' (ib.), to be used as bank reserves in the countries to be reconstructed, Keynes branded the existent American gold stock as 'lunatic' (and 'redundant'), a term he had already employed to qualify reserves accumulation in the United States in the interwar period, as well as to stigmatize rentiers' interest in holding money as a store of value.

As to Allied exchange policy, Britain in particular should act - here Keynes was quoting from his plans for the 1933 World Economic Conference - 'on spectacular lines with the object ... of striking the imagination of the world and of promoting confidence as well as securing resources' (CW 22, p. 173). The area should sign an international monetary and clearing agreement supplemented by uniform exchange and trade controls to protect itself from financial distress. Keynes believed his proposal to be 'so clothed and represented as to be actually palatable and preferable to the American authorities'. With respect to the last war, the proposal had 'the great advantage from their point of view that the measure of their financial assistance would be closely linked to their own exports' (p. 171). The clearing agreement would have abolished all loan transactions between the Allies. British assistance in goods and munitions to France would have been conceded as 'a free gift', thereby creating a precedent 'if and when the day comes for American participation' (ib.). To sum up, as he wrote to the Chancellor of the Exchequer on 11 June 1940, this time '[t]here shall be no question, as there was last time, of one Ally owing large sums to the other. All is freely given for the common cause now and hereafter' (p. 177), with the aim of 'trascend[ing] financial particularities' (p. 180).

The plan never saw the light. In deciding for assistance 'on a commercial basis', establishing financial relations 'on false commercial analogies' (CW 23, p. 25), America should not 'overlook the effect of what they may do on the post-war equilibrium of international trade' (p. 18). Likely a debtor since 1942 (Keynes was writing in October 1940), Britain would be compelled to establish 'a system of very strict bilateral agreements which would tie up the payment for our imports and our foreign debts with the acceptance of our exports by the other country' (p. 19). More in general, Keynes believed that the two nations should regard the arrangements of credits under the light of what they feel to be 'the right and proper thing ... exactly appropriate to the interests and responsibility of each and to the true character of the historical events in which we are participating' (p. 20). His conclusion was that 'the money involved is not of such importance to either party compared with the establishment of right relations, which will not lead to subsequent friction and estrangement, between the two countries' (ib.). Keynes went on to explain that his remarks about American financial assistance to Britain during the war should be considered in a much broader perspective, that of the international monetary system. "The U.S.A. already hold the greater part of the gold in the world. The only value of gold is as a means of settling international balances. If the convention - for it is no more by which gold is used for this purpose comes to an end, the U.S. Stock of gold becomes valueless. But the convention depends on not all the gold being in one hand. When in the game of 'Beggar my Neighbour' all the cards belong to one player, that is the signal for the game to come to an end. The pack becomes worthless 
paste-board; the fun is over' (25-26).

These considerations lie, exactly as Keynes's appreciation of the clearing principle, at the basis of the project of an International Clearing Union, which Keynes was to launch in late 1941. In his proposals to counter the German plan (June 1940) for a 'New Order' for post-war European economy, he stressed that the Allies, 'all members of one family', had a supreme duty 'to make our business, above most other purposes, to prevent the starvation of the post-armistice period, the currency disorders throughout Europe and the wild fluctuations of employment, markets and prices which were the cause of so much misery in the twenty years between the two wars; and we shall see to it that this shall be compatible with the proper liberty of each country over its own economic fortunes' (CW 25, p. 11). The Nazi plan had the merit of attempting to get rid of those 'laissez-faire currency arrangements whereby a country could be bankrupted, not because it lacked exportable goods, but merely because it lacked gold': international trade should have rather consisted in 'trading goods against goods', with gold confined to its function as 'central reserve and a means of international settlement' (p. 12). This required multilateral clearing of trade balances (so as to leave each country free to purchase from any other country within the agreement) with fixed but adjustable exchange rates. Shocking as it may have seemed at the time, Keynes's ideal system was quite close to the German scheme; only, the leadership of democratic Britain should have replaced Germany in creating 'a post-war order which seeks no particularistic advantage' (pp. 14-15).

What Keynes found to be revolutionary in the 'Schachtian device' was certainly the clearing principle which lay at the basis of the system of bilateral agreements established by Hjalmar Schacht, Hitler's Minister of Economics between 1934 and 1937, with European and Latin American countries to conduct trade without foreign exchange, as an international barter centered on Berlin. Keynes appreciated that the system avoids imposing undue pressures on debtor countries, and prevents undesired capital flows from debtor to creditor nations. Schachtianism appeared in Keynes's list of 'intensive laboratory experiment[s]' ( $C W$ 25, p. 22) tested during the interwar period in response to the secular international problem, and Keynes went so far as to hope that the system of the future would be a 'refinement and improvement of the Schachtian device' (p. 24). Mini (1994) is right to stress first that Keynes's Schachtian plans were meant for a world left alone by the United States - after all, 'Keynes's 1941 visit to the US left him deeply pessimistic as to the ability of that country to play anything other than a destabilizing role in the international economy' (Moggridge 2002, p. 118). Nevertheless, the system had two specific advantages: 'first, it substituted human intelligence for the failed automatisms of the past' (Mini 2006, p. 6). This could but please the author of Indian Currency and Finance, who had suggested to transform the unintended evolution of the Indian monetary regime towards a gold exchange standard into the ideal European currency system of the future, and of the Monetary Reform, where Keynes wrote that the alternative to gold was just 'our existing system, but worked self-consciously and for a wise, deliberate purpose' (CW 4, p. 161). Second, the system 'left any nation free to pursue its domestic policies without foreign interferences: never again should gold be allowed 
to rule the destinies of nations ... This demanded unlocking nations from each others' embrace, and this required jettisoning the gold standard and any other gold substitute that gave creditor nations the upper hand' (Mini 2006, pp. 6-7).

In fact, the only possibility to build a new international system able to combine 'economic efficiency, social justice and individual freedom' - the difficulty to mix these three elements, says Keynes in Liberalism and Labour, is the 'political problem of mankind' (CW 9, p. 311; see Backhouse and Bateman 2009) - was to ground it on a principle of 'common cause', of shared responsibility for international imbalances, and to grant a public-spirited institution the power to counteract tendencies to recur to rentier-like attitude, thereby 'socializing altruism' (Carabelli and De Vecchi 2001) to pursue social justice. The ICU plan was meant to recreate on a permanent basis the lucky historical conditions that had permitted harmonious relationships between 'old-established' and 'newly-developing' countries (CW 25, p. 22) - loans were 'self-liquidating because they themselves created new sources of payment' (p. 23) - in the pre-war gold standard. The belief that 'liberal credit and loan arrangements between the creditor and the debtor countries [flow] from the mere fact of an unbalanced creditor-debtor position' was based on a 'false analogy' (ib.). Only by compelling creditors to share the adjustment burden with debtor countries was it possible to grant 'a means of reassurance to a troubled world, by which any country whose own affairs are conducted with due prudence is relieved of anxiety, for causes which are not of its own making, concerning its ability to meet its international liabilities; and which will, therefore, make unnecessary those methods of restriction and discrimination which countries have adopted hitherto, not on their merits, but as measures of self-protection from disruptive outside forces' (p. 449).

'The post-war world must not be content with patchwork' (CW 25, p. 26), Keynes added to reject the alternatives of an ad hoc redistribution of the American gold or of a role of growth locomotive to be assigned to the United States. The new system should require 'the chief initiative from the creditor countries, whilst maintaining enough discipline in the debtor countries to prevent them from exploiting the new ease allowed them in living profligately beyond their means' (p. 30). Undesired capital flows, hitherto 'the major cause of instability' (p. 31), should be eliminated through strict controls as an essential feature of the new system. In the plan, the ICU issues a newly-created bank money (bancor) as the new international standard. Deficits and surpluses in the balance of payments would have been settled through the use of clearing accounts at the ICU, denominated in the new standard. Central banks would buy and sell their currencies against such liabilities and credits. 'What made the ICU revolutionary was that, by issuing its own currency, the ICU could create reserves as required' by the needs of international trade (Turnell 2002, p. 17). Each country was in fact given the opportunity to draw its own bancor quota, equal to half the average value of its total trade for the last five pre-war years. Exchange rates were fixed (in terms of a unit of bancor) but adjustable. As to the management of international disequilibria, creditor countries would be allowed and, the case being, required to revalue their currencies and unblock foreign investments. Credits exceeding in amount a quarter 
of their quota would be charged rising interest rates; those exceeding the quota itself at the end of a year would have been directly transferred to the ICU. Symmetrically, debtor countries would be allowed or asked to devalue their currencies, to sell gold and to prohibit capital exports; their excessive debts would have been charged interest, though lower than those applied to creditors' excessive balances.

The 'heart of the matter', Moggridge argues, 'was to encourage balance of payments adjustment' (1992, p. 674). But the plan also sought 'to protect the economic vision implicit in The General Theory from the power of the rentier nations' (Mini 1994, p. 194; see also Meltzer 1989). At the basis of the 'revolution' of the ICU was what Keynes defined as the 'banking principle', a portentous direct attack against rentiers. 'The idea underlying my proposals for a Currency Union is simple, namely to generalise the essential principles of banking, as it is exhibited within any closed system, through the establishment of an International Clearing Bank. The principle is the necessary equality of credits and debits, of assets and liabilities. If no credits are removed outside the banking system but only transferred within it, the Bank itself can never be in difficulties' (CW 25, p. 44). Remindful of the General Theory, the ICU system deals with a closed world: at the supranational level, international imbalances reduce to zero. As Keynes had observed in the Twenties, that between 'the debt of the individual' and 'the debt of the state' is a 'false analogy. There is no real analogy between the two. An individual's motives for clearing himself of debt may apply to the external obligations of the state; but they can have no application to its internal obligations' (CW 19, p. 368). Once however the world is closed, so to speak, by the ICU, the 'dead hand of debt' cannot impose its burden any longer on the system's members. As Keynes himself remarks in the third draft of the plan, facilities allowed to countries by the system 'are made possible by the nature of the system itself and do not involve particular indebtedness between one member state and another. A country is in credit or debit with the Currency Union as a whole. This means that the overdraft facilities, whilst a relief to some, are not a real burden to others' (CW 25, p. 74).

So much for Keynes's first criticism of rentiers. But creditor countries would not have found it in their interest any longer to demand money instead of goods. 'In the first days of banking great stress was laid on the possession of capital but we have learned as time goes on that it is of insignificant importance. You need the capital if you are not in a closed system and have to meet liabilities for credit outside your system, but in a closed system you can reach your conclusion by simply off-setting the deposits of some members against the overdrafts of others. The deposits on the one side are necessarily exactly equal to the overdrafts on the other, so that as there is no lability to pay outside the system it involves no risk and therefore requires no capital' (CW 25, p. 210). Creditors will not feel any advantage in hoarding surplus resources, since '[n]o country need be in possession of a credit balance unless it deliberately prefers to sell more than it buys (or lends); no country becomes unliquid or is prevented from employing its credit balance whenever it chooses to do so; and no country suffers injury (but on the contrary) by the fact that the balance, which it does not choose to employ for the time being is not withdrawn from circulation' (pp. 74-75). 
Creditors are allowed the possibility to choose how to employ their surpluses - expansion of credit and domestic demand, currency appreciation or wages increase, abatement of trade restrictions or foreign lending for development - provided they effectively use them, to avoid being charged interests on their excessive balances, instead of 'remain[ing] entirely passive' (CW 25, p. 78). In Keynes's words: '[i]n the absence of the Clearing Union a creditor country can employ the proceeds of its exports to buy goods or to buy investments, or to make temporary advances and to hold temporary overseas balances, or to buy gold in the market. All these facilities will remain at its disposal. The difference is that in the absence of the Clearing Union, more or less automatic forces come into play to restrict the volume of its exports after the above means of receiving payment for them have been exhausted. Certain countries become unable to buy and, in addition to this, there is an automatic tendency towards a general slump in international trade and, as a result, a reduction in the exports of the creditor country. Thus, the effect of the Clearing Union is to give the creditor country a choice between voluntarily curtailing its exports to the same extent that they would have been involuntarily curtailed in the absence of the Clearing Union, or, alternatively, of allowing its exports to continue and accumulating the excess receipts in the form of bancor balances for the time being' (p. 457).

Finally, Keynes gets rid of the functionless international rentier. His proposal 'aims at the substitution of an expansionist, in place of a contractionist, pressure on world trade' (CW 25, p. 74). 'Evils' ensued in the past for debtor countries from creditors remaining passive, but the virtuous of the banking principle were simply miraculous. 'The substitution of a credit mechanism in place of hoarding would have repeated in the international field the same miracle already performed in the domestic field of turning a stone into bread' (p. 114). The turnabout, with respect to 'the utilitarian and economic - one might almost say financial - ideal, as the sole, respectable purpose of community as a whole ... Bread and nothing but bread, and not even bread, and bread accumulating at compound interest until it has turned into a stone' (CW 28, p. 342), was complete. As remarked by Mini, the plan projected 'some of the ideas of the 'Economic Possibilities for Our Grandchildren' into the international arena' (1994, p. 194). It simply 'obliterates the ancient notion that in matters of international trade a specie inflow is the just reward of virtue (thrift, efficiency, hard work) while a trade deficit is the punishment for profligacy, high living, inefficiency' (p. 193).

Keynes believed the scarcity of capital to be simply artificial. The General Theory assigns to the state the task of providing investable funds for the entrepreneurs through a policy of 'socialisation of investment' (CW 7, p. 378) which should bring rentiers to euthanasia. For Keynes, the stock of capital available for investments could be so enlarged as to drive expected profit rates down to zero in a single generation. The ICU was required to accomplish a similar task at the international level. It could operate so as to eliminate the occurrence of deficits and surpluses: '[t]here is great force in the contention that, if active employment and ample purchasing power can be sustained in the main centres of world trade, the problem of surpluses and unwanted exports will largely disappear even though under the most prosperous conditions there may remain some disturbances of trade and unforeseen situations requiring special remedies' (CW 25, p. 116). The 
combination of banking principle and bancor would have reduced the weight of gold in international economic relations and provided sufficient reserves for world trade.

On commenting the first draft of Harry Dexter White's plan for a Stabilisation Fund, Keynes remarked that the scheme was 'only helpful to those countries which have a gold reserve already and is only helpful to them in proportion to the amount of such gold reserve. If, however, a country has only a little gold and, therefore, needs much support, the scheme provides on the contrary that it shall receive only a little support. To him that hath it is given. No adequate provision is offered for what happens when the resources provided, which in some cases would be exceedingly moderate, have been used up' (CW 25, p. 160). White's plan was simply too adherent to the gold standard: the volume of international currency could not be adjusted to need, and punishment and rewards were still there. Curiously enough, Keynes explained more accurately how the ICU could attain this result than how the state could bring about the end of 'the cumulative oppressive power of the capitalist to exploit the scarcity-value of capital' (p. 376). But this analogy is certainly not a false one, as shown by Keynes himself: '[t]he world's trading difficulties ... may be caused in a most acute form if a creditor country is constantly withdrawing international money from circulation and hoarding it, thus refusing to spend its income from abroad either on goods for home consumption or on investment overseas. We have lately come to understand more clearly than before how employment and the creation of new incomes out of new production can only be maintained through the expenditure on goods and services of the income previously earned. This is equally true of home trade and of foreign trade. A foreign country equally can be the ultimate cause of unemployment by hoarding beyond the reasonable requirements of precaution' (pp. 272-73).

\section{MORALS RATHER THAN FINANCE? ON THE NEGOTIATIONS OF THE 1945 AMERICAN LOAN}

Much of the literature overlooks that the explicit connection established by Keynes himself between American financial assistance to Britain during and after the war and the plans for global reform. In the second draft of the ICU plan, he clarified that '[t]he assistance for which we can hope must be indirect and a consequence of setting the world as a whole on its feet and of laying the foundations of a sounder political economy between all nations' (CW 25, p. 43). Not only, but assistance would come only '[i]f we are to attract the interest and enthusiasm of the Americans, we must come with an ambitious plan of an international complexion, suitable to serve the interests of others besides ourselves, which to a hopeful spirit may carry a chance of making the post-war economy of the world more reasonable and promising than it was before' (ib.). In trying to solve her problems in the transition to the new order, Britain should not be contented with patchwork solutions, since it would be surely more satisfactory 'to persuade the U.S. to enter into a general and collective responsibility, applying to all countries alike, that a country finding itself in a creditor position against the rest of the world as a whole should enter into an obligation to dispose of this credit balance and not 
to allow it meanwhile to exercise a contractionist pressure against the world economy and, by repercussion, against the economy of the creditor country itself' (p. 47).

The final Bretton Woods agreement had left the newly created international institutions with scarce resources to deal with the transition to the post-war order. Having 'held the [European] fort alone' (CW 24, p. 609) during the first years of the war, Britain was now facing four external problems (see Pressnell 1986, 2003): first, the expiration of American and Canadian financial assistance to Britain under the Lend Lease agreement of March 1941. Second, enormous wartime financial obligations - the balances of the sterling area countries in particular, who had accepted to centralize their gold and foreign exchange reserves in London in exchange for sterling -, which Keynes saw as a reflection of the practical impossibility to revise the financial responsibilities for the war between Britain and the United States since they entered the war. Third, the need of external long-term finance, in particular from America, to ease a dramatic transition to the post-war order. Fourth, the commitment, established by Roosevelt as the price for Lend-Lease to the free-trade post-war world embodied in the famous "Article VII" of the Mutual Aid Agreement of February 1942.

Scarcity of reserves, the burden of expenditures for relief and reconstruction and the gloomy prospects of Britain's exports in the post-war period could but reduce the chances of balancing Britain's external account in the transition period while returning to sterling convertibility. Transition to peacetime would have seen Britain burdened with a cumulative deficit of $£ 2$ billion ( $\$ 8$ billion) to be borrowed outside the sterling area, which would have certainly registered an overall deficit after the war. London could invoke a new settlement of the financial sharing of defence by the Sterling Dominions, who had built up 'war profits at our expense' (CW 24, p. 268); yet, having 'persuaded the other countries concerned to entrust us with virtually the whole of their accruing external reserves', Britain could not, in Keynes's view, 'refuse to make at least part of these available in so far as they are required for immediate needs' (p. 8). As Keynes had successfully prophetized in 1942, therefore, Britain would have run the risk, at the end of the war, of appearing as an illegitimate beggar: '[u]nless we can discover some better and clearer manifest, we, who will in fact have borne the brunt of the financial sacrifice of the war and literally alone amongst the Allies will have suffered a serious reversal of our overseas financial position, will appear as having, on the one hand, played a nasty confidence trick on the rest of the sterling area, and on the other, as having deceived our American friends into putting more money than we really required' (CW 23, pp. 247-48).

\section{Overseas Financial Policy in Stage III}

In response to the prospected expiration of the Lend Lease Agreement, Keynes designed, in his memorandum 'Overseas Financial Policy in Stage III' of March 1945, a 'bold scheme for an international policy of multilateralism in trade and payments that would simultaneously make sterling's problems more manageable and justify Britain in seeking and America in giving financial assistance' (Pressnell 1986, p. 237). Keynes knew that 'the financial and commercial arrangements of a considerable section of the world have 
become almost inextricably intertwined with our own financial and economic affairs in London' (CW 24, p. 462), so that the three mutually exclusive scenarios for Britain's future depicted in the memorandum were also those of global multilateralism. In the absence of American assistance, Britain would find herself confined in a 'Starvation Corner', having to adopt a unilateral policy of austerity and isolationism at a moment when, due to the overall deficit of the sterling area, she had inevitably to resort to foreign borrowing to finance her debts. The Schachtian consequences of this scenario would have favored 'not merely the acceptance but the advocacy ... of a system of international economy after the war of a kind to which all sections of opinion, not only in the United States but also in Canada, are bitterly opposed' (pp. 27172). In Keynes's second scenario, 'Temptation', Britain receives American financial assistance in the form of a loan (\$5-8 billion) on easy terms, allowing Britain the breathing space to face the transition to the new order and to approach its debt problems with the sterling area. In exchange for the loan, London should have guaranteed free multilateral clearing within the area from the outset and the dismantlement of the empire, thereby coming to accept the 'American conception of the international economic system' (p. 61) which Roosevelt had established as the price of the Lend-Lease agreement.

Yielding to Temptation, in other words, Britain would have been forced (not differently from Germany) 'into conformity with an economic policy designed from without', and compelled to ask for 'mercy and deferment' (CW 24, p. 278). 'It is not as the result of some statistical calculation about what we might be able to manage', Keynes claimed, 'that the mind revolts from accepting the counsels of Temptation. The fundamental reasons for rejection are incommensurable in terms of cash' (ib.). The American loan would have in fact sacrificed 'the sweet breath of Justice between partners' in the war 'to some false analogy of 'business" (p. 279). As Keynes had observed, in perfect continuity with his statements on WWI Inter-Allied debts, '[t]o commercialise a war debt between Allies which leaves no productive asset behind, would be unreasonable and wrong. Interest, where there is not and in the nature of things could not have been any current income yielded by the loan has been stigmatised in most ages of history, except when the false analogies of trade were wholly dominant, as an intolerable and immoral imposition. To repay capital instalments is bad enough when no asset corresponds to the loan. But it is honourable, having received assistance in kind, to return the equivalent as time and opportunity permits' (p. 48).

Only 'Justice', that is 'a general re-consideration of the proper burden of the costs of the war', could allow Britain to be the Americans' partner 'in setting up a post-war international economy of the character on which they have set their hearts' (CW 24, p. 280). In addition to the $\$ 5$ billion credit line at easy conditions of 'Temptation', 'Justice' required the United States to grant Britain $\$ 3$ billion as a sort of retrospective LendLease agreement. In exchange, Britain would have guaranteed the de facto convertibility of sterling (initially limited to the area's current earnings) within a year after the termination of war. This kind of support would have made it possible for Britain to approach the members of the sterling area, called upon to contribute a proportion of their balances 'to the costs of the common victory' (p. 281), with proposals for solving the 
sterling balances problem. Such liabilities would have been divided into three portions, one part to be made fully convertible and available to meet a deficit on current account ( $₫ 750$ million), one part to be funded ( $£ 1,500$ million) and one part to be cancelled ( $£ 880$ million). Allowing for such mitigations, Britain would then be left with sufficient gold and exchange reserves and a not intolerable liabilities/reserves ratio to face 'the economic future without any serious anxiety' (p. 290). For reasons of 'honour', 'justice' and 'practice', Britain could not resort to debt repudiation. Unless such burdens were mitigated, however, Britain could not 'for several years to come participate in the free international economy upon which the Americans have set their hearts and which we also, no less than they, vastly prefer if it is made practicable for us' (p. 291). The United States, Keynes concluded, 'will never have a better chance of a wise act at so modest a cost' (ib.): \$3 billion were the war cost for the Americans for a fortnight, he commented, adding that such contribution would enable them 'to dispose over a period of foreign surplus far below what they are likely in any case to develop, a surplus of which in any case they will have to find means of riddance' (ib.).

\section{The proposal of an American gift}

As known, Keynes lost his battle: in the end, Washington offered a generous loan (3.75 billions dollar on easy terms), and Britain, pace Keynes, accepted it. Did Keynes really hope for, and count on, an American gift to Britain, as maintained by Harrod (1951) and Gardner (1980)? As seen, Skidelsky (2000) believes so, but sees the proposal as Keynes's most important mistake in his fighting for Britain. In this regard, morals may certainly be an illusion, as Skidelsky argues, but also a tactic: Ferrrari Bravo argues that Keynes had no alternative to avoid projecting himself 'immediately in that realm of utilitarian considerations towards which the stronger financial counterpart tended to move' (1990, p. 272, our translation). In Pressnell's account (1986), Keynes's proposal as agreed on in the major meeting of the British negotiators on 23 August 1945 was a strategic camouflage of the expected loan, 'not so much serious beliefs as an attractive marker, to compare the most favourable possible outcome with the least favourable' (p. 265). 'The aim was to seek at the outset, not unnaturally, preferred British goals', says Pressnell: the proposal of an American gift could serve as an excuse to complain of the final loan agreement, which 'even if regarded as broadly reasonable in London, should nevertheless appear to be of American inspiration' (p. 266).

It is our belief that by neatly separating ethics from economics, that is by failing to consider the ethical dimension of Keynes's diplomacy, both these interpretations of the proposal of an American gift, the 'gift as tactic' view and Skidelsky's 'morals rather than finance' argument, cannot avoid a reductionist stance. The correspondence on the proposal, in Spring 1945, between Keynes and the treasury representative in Washington, Robert H. Brand, helps remedy this omission (see Carabelli and Cedrini 2010c). On commenting Keynes's memorandum, Brand argued that what Britain could propose as justice for her, on the basis of the United States' late entry into the war, would not be considered by the Americans as justice for them. It was likely in the interest of the United States to help Britain; yet, '[i]f they were to give [a gift], the 
Americans would certainly regard it as an act, not of justice, but of generosity', he stressed, and suggested asking for 'something that looked a little less like a free gift' (CW 24, p. 308). Keynes disagreed. Since ' [t]he various elements in the policy of trying to march with the U.S. in the post-war economic set-up all hang together' (p. 316), only an American gift could allow Britain to reach a satisfactory settlement with its sterling creditors and guarantee the United States the desired measure of convertibility. Temptation would impose their burden of 'distasteful' second-best policies for Britain, policies which would prove 'objectionable' (ib.) to the Americans and carry the risk of an 'unbalanced settlement' (p. 317) with them. The gift was thus, in Keynes's view, a strictly necessary condition for keeping up with the declared commitment towards free trade.

In fact, Keynes stood resolutely against 'anything in the nature of a specific bargain' (CW 24, p. 324). 'The appeal to justice', he observed in a letter to Sir Wilfrid Eady of the Treasury, 'does not necessarily suggest any lack of generosity on the part of U.S. It is a wider conception about the way in which the financial consequences of the war should be liquidated' (p. 360). '[T]oo exclusive an appeal to American selfinterest' might have been 'misjudged' (ib.), but America was, as he later wrote in a memorandum to Hugh Dalton, a 'business country where it is a moral duty and not merely a self-regarding act to make any money which the traffic will bear and the law allow' (p. 548). This required 'some imitation of a normal banking transaction' (ib.). Still, the unspecific bargain Keynes had in mind was simply that between the American gift and Britain's acceptance of 'the kind of post-war world' (p. 328) wanted by the Americans themselves, namely the multilateral world of free trade that the United States would otherwise 'fail to get, here and now' (ib.). For instance, the United States could demand a commitment by the sterling countries to have a part in the reconstruction of Britain. It could thus be settled that 'the $\$ 3$ billion from the U.S. should be matched by cancellations by the sterling creditors of an at least equal amount' (p. 324). Finally, Keynes brought forward a non-economic argument supporting the idea of the gift at least as an 'opening gambit' (p. 339). A gift would facilitate the task of prompting the sterling area countries to fall in with the proposal: 'If America insists on remaining on a strictly economic basis, that makes it harder for the others to depart from it. I attach predominant importance to this psychological atmosphere of the free gift' (p. 340).

Keynes's correspondence with Brand makes it evident that in his 1945 diplomacy, Keynes was using an updated version of the model of international adjustment implicit in his suggestions for the settlement of reparations and Inter-Allied debts at the end of World War I. Britain was now at the center of a generalized conflict involving virtually all members of a highly imbalanced interdependent world, inhabited by only one surplus country and a plethora of deficit nations compelled to choose between the return to distasteful isolationist interwar policies and the acceptance of a new sounder order for which they were financially unprepared. Keynes's 1945 memorandum and his writings in economic diplomacy at the end of World War I have in common their ultimate aim, namely to revamp global multilateralism, as well as the means to achieve this result, that is a 'gift dynamics' to promote a multilateral resolution of global imbalances. The 
involvement of a third actor - European creditors at the end of the First World War and the sterling area in 1945 - in a process which looks as (and has been traditionally treated as such) a bilateral relationship, is typical of gift-giving situations, and sheds light on the systemic character of gifts, which link together 'many partners in a chain, creating a complex path' (Godbout 2000, p. 130; see Cedrini 2010). The moving from the Starvation Corner toward Justice, passing through Temptation, is to be seen as the progressive enlargement of the spectrum of countries taking part in the adjustment to a more equilibrated world. Justice and the 'American Gift', the starting mechanism of this chain of generosity, was in Keynes's view the only possibility to induce the sterling countries to play the part they only could play in revitalizing world trade through their exchanges with America (see De Cecco 1979). The economic necessity of the Marshall plan after the 1947 sterling convertibility crisis was later to confirm that the defence of Britain's destiny was in truth that of 'the considerable section of the world' whose economic affairs had become 'almost inextricably intertwined' with those of London.

\section{KEYNES'S ETHICS OF INTERNATIONAL ECONOMIC RELATIONS}

At least on one point, Skidelsky's account of Keynes's diplomacy at the end of World War II is correct. The analysis of Keynes's ethics of international economic relations shows in effect, as the historian claims in his latest book (2009), that justice was not an end in Keynes's vision, exactly as it was not in Moore's philosophy. Keynes treated justice instrumentally, as a means to a good life, which is in his vision the ultimate ethical end. 'Controversies as to relative sacrifice are very barren and very foolish also; for there is no reason in the world why relative sacrifice should be equal - so many other very relevant considerations being quite different in the two cases' (CW 2, p. 174), says the Keynes of The Economic Consequences of the Peace. As seen, his comparisons of relative sacrifices after the two world wars were generically inspired to an idea of justice as 'fairness' (see Skidelsky 2009) and equity. Yet in 1945, Keynes found the fact that Britain had held the fort alone for the first years of war a compelling reason for asking the Americans and the sterling countries to fairly contribute to costs of the conflict. After all, even in case of American assistance of the kind desired by Keynes, the British would 'still remain the only country in the Alliance left at the end of the war with its overseas earnings heavily mortgaged as a result of it - most of the others would still find themselves in substantial profit at our expense. We should still have fought, so to speak, as the only non-mercenaries' ( $\mathrm{CW}$ 24, p. 289).

Keynes could see the rest of the Allies as 'mercenaries', at the end of the war, because he believed it morally wrong to make profits from a war which was in truth a 'common cause' among friends. The antiutilitarianism of his vision of international relationships shows that morals was not a veil to him. Awareness of the non-economic character of war debts coupled with that of the evils they were to impose on international relations uncovers the various false analogies of economicistic nature produced by purposiveness, love of money and the overestimation of the economic problem in human society. As 
happens in the General Theory (see Carabelli 1991) with the classical theory, Keynes's criticism of the American view of Inter-Allied debts is first of all of a methodological nature: after discovering the (economistic) hypotheses tacitly introduced in this reasoning and finding that their validity is limited to particular cases, Keynes is able to conclude that the analogy between such debts and ordinary business investments is a false one.

Still, at the end of World War I, Keynes had counted on 'foreign trade arguments' to persuade the United States to sustain the European recovery, whereas during the interwar period, in peacetime - that is, when debts among nations are effectively of a commercial nature - he came to develop an even more violent criticism of the rentier-like attitude of creditor countries, and to accuse the latter of failure to take responsibility for the managing of global imbalances. His moral criticism of the Temptation option in 1945 is remindful of the attack launched on rentier nations during the interwar period, when creditors had ceased to be 'reasonable', although it was now their duty to be so. This change does not rest on an absolute radicalization of his ethics; rather, in line with Burke's political philosophy, duty in Keynes's view is relative to times and circumstances. When the latter change, duties change too (see Helburn 1992).

Keynes's battle against the burden of WWI Inter-Allied debts wars was inspired by his belief that the international economic problem was but 'a transitory and an unnecessary muddle' (CW 9, p. xvii) absurdly denying countries the possibility to free themselves from economic pressures and anxieties. Then, having demonstrated that the golden fetters of the badly-ruled interwar gold standard were responsible for the economic disaster of the Thirties, Keynes reshaped the global order in such a way as to defuse what he had come to define as the dilemma of the international system, that between international discipline and national autonomy. The appearance of the dilemma and accrued awareness of the rentier-like nature of creditor nations' behaviour in the interwar period led Keynes to fix more precisely the boundaries of his antiutilitarian view of international economic relations.

In Keynes's vision, economics is concerned with providing men the material preconditions for the enjoyment of a happy life and the possibility of individual choice of ends. Freedom from economic pressures discloses 'the possibilities of personal life' (CW 9, p. 125): more precisely, therefore, 'freedom' in Keynes's philosophy is to be intended as 'freedom to choose'. When Keynes refers to the 'dilemma of the international system', he is using the term 'dilemma' in a precise way, which he had already defined in his early writings on ethics (see Carabelli 1998; Carabelli and Cedrini 2009). Moral and rational dilemmas derive from the existence of a plurality and variety of heterogeneous goodness, moral ends and values, or reasons and evidences for action, which both imply the possibility of a clash between irreconcilable claims. The dilemma between international discipline and national autonomy compels the system's countries to decide what to privilege and what to sacrifice in the search for national economic welfare. Finding himself a sure victim of the dilemma, Keynes had no doubt, and opted for National Self-Sufficiency, at an epoch when Britain was suffering 'not because we are poorer than we were but because other values seem to have been sacrificed and 
because they seem to have been sacrificed unnecessarily, inasmuch as our economic system is not, in fact, enabling us to exploit to the utmost the possibilities for economic wealth afforded by the progress of our technique, but falls far short of this, leading us to feel that we might as well have used up the margin in more satisfying ways' (CW 21, pp. 242-43).

The shaping of the new Bretton Woods order provided Keynes with the opportunity to solve the dilemma. The attention he had posed on the morals of international debts and the clash between the competing interests of rentier nations and those of the system as a whole helped him identify, in continuity with his analysis of domestic economies, the need for a public-spirited international institution able to able to remedy to the negative effects of social complexity (such as fallacies of composition, prevalence of conventional over reasonable expectations, and so on). Yet, in establishing the rules of the new desired global order, Keynes insisted more on the freedom and autonomy of the system's members than on the obligations imposed to them by the new international discipline. Trying to defend the ICU plan from various criticisms over time, he declared that the plan 'leaves each country to be the judge of its own needs' (CW 25, p. 276), whereas the other experiments of the interwar laboratory were likely to be influenced 'by extraneous, political reasons' and tended to put 'individual countries in a position of particular obligation towards others' (p. 178). Since the banking principle was but an extension of the 'impersonal' methods of any domestic banking system (p. 192) to the international sphere, debtor countries would have been dependent on the 'anonymous and impersonal aid of the system as a whole' (p. 193). In general, Keynes stressed that '[n]o particular member states have to engage their own resources as such to the support of other particular states or any of the international projects or policies adopted' (p. 191) by the ICU. As to surplus countries, he pointed out that the plan included 'no provision by which the creditor is limited in his liability to accept a credit balance with the institution if he chooses not to use it ... He is still left with every conceivable liberty he has now' (pp. 211-212). More, the plan was an 'extra facility' to the creditor country, 'for it allows it to carry on its trade with the rest of the world unimpeded, whenever a time lag between earning and spending happens to suit its own convenience' (p. 276).

Keynes regarded the ICU as "a measure of financial disarmament" (CW 25, p. 57) which would favour 'not only ... the general advantage but also ... the individual advantage of each of the participants' (p. 235). It was the duty's plan to avoid repeating 'the error of the gold standard', which 'lay in submitting national wage-policies to outside dictation. It is wiser to regard stability (or otherwise) of internal prices as a matter of internal policy and politics' (CW 26, p. 33). It was an 'illusion', he had written in 1935, 'that the international system of the future must necessarily be a uniform one' (CW 21, p. 356). Keynes firmly believed that 'there should be the least possible interference with internal national policies and the plan should not wander from the international terrain' (CW 25, p. 234). In Kirshner's (2009) view, the ultimate reason why Keynes struggled against laissez-faire as regards international capital movements was his conviction that 'distinct national circumstances implied that heterogeneity, not homogeneity was appropriate across various 
states' macroeconomic policies' (p. 534). But such heterogeneity cannot manifest itself except in a global order leaving its member countries free to choose among different national policies.

Keynes's diplomacy in the context of the negotiations of the American loan offers relevant information on the traits of his desired new order. As seen, aiming at providing a truly multilateral response to post-war imbalances, the proposal of an American gift provides clear continuity with the ICU plan. More importantly, however, a gift-giving analysis of Keynes's proposal demonstrates that 'Overseas Financial Policy in Stage III' truly embodies the same revolutionary spirit of Keynes's desired new system, to the extent that it has been correctly described as 'a trigger mechanism for the creation of a Keynesian world' (Newton 2000, p. 199). After borrowing Marshall Sahlins's (1972) work on the norm of reciprocity, Keynes's desired global order may be described as the attempt to leave aside the 'negative reciprocity' of the interwar period when countries 'confront[ed] each other as opposed interests, each looking to maximize utility at the other's expense' (p. 195) - to endorse the 'balanced reciprocity' which is typical of orders where social relationships depend on material flows. Since systems governed by a norm of perfectly balanced reciprocity are generally unstable and likely to degenerate into a state of exploitative social relationships, the balanced reciprocity of the 'banking principle' in Keynes's scheme must be supplemented by sanctions such as those that strengthened the 'shared responsibilities' principle of the ICU, or be helped to progressively approach the 'positive reciprocity' model implicit in the proposal of an American gift.

A gift-giving analysis of Keynes's proposal shows however that this is not the whole story. Modernity, and economics in primis, tend to repudiate the complexity of the gift by defining it through one and only one of its various components (interest and disinterest, egoism and altruism, freedom and obligation; see Caillé 1998). This way, the so-called paradox of the free gift is bound to arise - 'there is no gift that brings a higher return than the free gift, the gift given with no strings attached' (Gouldner 1973, p. 277), yet '[a] gift that does nothing to enhance solidarity is a contradiction', as Mary Douglas argues (1990, p. vii) on commenting Marcel Mauss's The Gift. Unable to bring into question its 'most basic Law', namely 'that one cannot get something for nothing' (Harrod 1948, p. 36), economics in particular cannot succeed in grasping the "between" character of the gift relationship (see Zenou et al., 1993). A prolongation but also a different vehicle of the spirit of Keynes's plans to reform the global architecture, the proposal of an American gift is characterized by a play of freedom and obligation of the same kind of that discussed by Mauss in his masterpiece.

In his speech to the Lords of 23 May 1944, Keynes stressed that the 'shared responsibility' principle of the Joint Statement of Bretton Woods would not have been possible without 'a voluntary undertaking, genuinely offered in the spirit both of a good neighbour and, I should add, of enlightened self-interest, not to allow a repetition of a chain of events which between the wars did more than any other single factor to destroy the world's economic balance and to prepare a seed-bed for foul growths' (CW 26, p. 14). This association of 'voluntarism' with 'enlightened self-interest' parallels Keynes's opinion about the absence of 
any 'obligation' (CW 18, p. 300), for the Americans, to comply with his proposals for a mitigation of WWI Inter-Allied debts, which the United States could not be expected to offer 'unconditionally' (p. 299). And, to come to the American gift proposal, Keynes never asked directly for it, since he wanted the Americans themselves to make the offer in recognition of Britain's effort in financing the war. Nevertheless, the Americans were 'greatly at fault, in [his] judgement, for having no constructive proposals whatever to offer to a suffering and distracted Europe' (CW 2, p. 94) in the negotiations of Versailles. And, on defending the American loan agreement in his speech to the House of Lords of 18 December 1945, he went so far as to admit 'I shall never so long as I live cease to regret that this is not an interest-free loan. The charging of interest is out of tune with the underlying realities. It is based on a false analogy' (CW 24, p. 613).

The pattern of social interactions implicit in Keynes's diplomacy with the Americans in particular is therefore far from simple. In the correspondence with Brand on the 1945 memorandum, Keynes stresses the need to avoid a specific bargain between American assistance and Britain's commitment towards free global trade. In short, he insists on unconditionality. The 'psychological atmosphere of the free gift' should serve as a means of reaching a settlement which would have been otherwise impossible to attain by agreement; the element 'chang[ing] the environment within which individuals operate', inducing 'behaviour to conform to goals which were attainable only bypassing individualistic motivation or utilitarian calculations' (Marcuzzo 2008, p. 36). Keynes's approach was thus based not on ambiguity-resolving devices, but on the structural uncertainty that is typical of gift-giving situations, wherein it plays the role of precondition for establishing a social bond between actors previously regarding each other as rivals (see Godbout 1998). It was, in other terms, an approach of 'conditional unconditionality', that is of an unconditionality which is in truth conditional to the appearance of positive interactions and necessarily lives under the threat of falling back to the unconditional diffidence of the clash of interests (see Caillé 1998).

That measure of social indebtedness which Keynes desired every partner involved to positively appreciate as a precondition for working together on a new world order was based on clearing up not the past, but its dramatic consequences on the future, in the form of market indebtedness - as Keynes himself declared in his speech to the Lords, 'in no phase of human experience does the past operate so directly and arithmetically as we were trying to contend. Men's sympathies and less calculated impulses are drawn from their memories of comradeship, but their contemporary acts are generally directed towards influencing the future and not towards pensioning the past' (CW 24, p. 610). As any gift, Keynes's American gift is inhabited by a strange mix of freedom and obligation, where 'the obligation to give is a paradoxical obligation to be free and to oblige others to be free too' (Caillé 2005, p. 6). Britain's countergift to the United States was the promise to help the Americans to develop the kind of post-war world they desired. Only a gift, in fact, could allow Britain the 'real liberty of action' needed 'to offer from the start the full multilateralism of trade and exchange which will be the best inducement to the Americans to fall in with our proposals' (CW 24, p. 276). But this was also the post-war world Britain herself desired: the Americans had the possibility to 'make us an 
offer, not so much generous as just, using their financial strength not as an instrument to force us to their will, but as a means of making it possible for us to participate in arrangements which we ourselves prefer on their merits if only they can be made practicable for us' (p. 272). Contrary to common sense interpretations of gift-giving situations in terms of the power of the donor on the donee, Keynes adopts a Maussian view of exchange, and stresses that the difference between a loan and a gift lies in the repercussions they would respectively have on the freedom to choose of the receiver. Granting a loan, the Americans would have forced Britain to their will, that is to accept the American conception of the international economic system. Offering a gift as 'an act that widens the scope of freedom for the members of a society' (Godbout 1998, p. 190), they would have granted Britain the freedom to proactively choose and help to shape the multilateral option.

Keynes's proposal of an American gift shows therefore that Skidelsky's 'morals rather than finance' argument is ill-conceived. For Keynes, morals and finance were both means to a non-material end, namely the autonomy of individual judgement and the possibility of individual choice of ends. 'Of greater and more permanent significance' than the 'supposed necessities' of the economic problem (CW 9, p. 332), freedom to choose is the key for attaining what 'the future holds in store for us', that is 'more wealth and economic freedom and possibilities of personal life than the past has ever offered. There is no reason why we should not feel ourselves free to be bold, to be open, to experiment, to take action, to try the possibility of things' (CW 9, pp. 124-25). In the General Theory, Keynes justifies his calls for 'central controls' (CW 7, p. 379) as means to attain full employment while safeguarding the 'traditional advantages of individualism', which 'is the best safeguard of personal liberty in the sense that, compared with any other system, it greatly widens the field for the exercise of personal choice. It is also the best safeguard of the variety of life, which emerges precisely from this extended field of personal choice' (p. 380).

Under this light, 'Overseas Financial Policy in Stage III' finally appear as a tester of the leader's willingness to comply with the revolutionary spirit of the desired new system, despite the rejection of the 'freedom-enhancing' proposals advanced by Keynes for Bretton Woods. As a public institution explicitly designed to favour the general interest, the ICU was assigned by Keynes the 'duty to be altruistic, in defence of the individual' (Carabelli and De Vecchi 2001, p. 244), that is of the individual country and its right to autonomous judgement. Keynes defended the Anglo-American negotiations in the Forties as the 'first great attempt at organizing international order out of the chaos of the war in a way which will not interfere with the diversity of national policy yet which will minimize the causes of friction and ill will between nations' (CW 24, p. 608). The unrestricted laissez-faire of the late gold standard and interwar period had 'mistake[n] private licence for public liberty' (CW 24, p. 622): it was thus 'an advantage of the [ICU] scheme that it invites the member states to abandon their licence to promote indiscipline, disorder and bad-neighbourliness which, to the general disadvantage, they have been free to exercise hitherto' (p. 195). The multilateral clearing agreement designed by Keynes was destined to reduce the tensions between national autonomy and 
international discipline which necessarily derive from global interdependence. His desired international system would have been able to solve by itself the dilemmas it raises by managing the co-habitation of different varieties of national capitalism instead of reducing them to a one-size-fits-all set of right policies and standards. If Keynes used moral arguments in his economic diplomacy, he did so to aid the cause of an ethics of international economic relations wherein discipline is exercised not against, but in favour of national policy space.

\section{REFERENCES}

Alessandrini, Pietro and Michele Fratianni (2009). Resurrecting Keynes to Stabilize the International Monetary System, Open Economies Review. 20(3): 339-358.

Backhouse, Roger E. and Bradley W. Bateman (2009). Keynes and Capitalism, History of Political Economy. 41(4): 645-671.

Bernanke, Ben S. (2005). The Global Saving Glut and the U.S. Current Account Defi cit, Remarks at the Sandridge Lecture, Virginia Association of Economics, Richmond, Virginia, March 10, URL: http://www.federalreserve.gov/boarddocs/speeches/2005/200503102/default.htm.

Boughton, James M. (2002). Why White, not Keynes? Inventing the Postwar International Monetary System, International Monetary Fund Working paper 02/52.

Burk, Kathleen (1979). J.M. Keynes and the Exchange Rate Crisis of July 1917, The Economic History Review, New Series. 32: 405-416.

Caillé, Alain (1998). Il terzo paradigma. Antropologia filosofica del dono. Torino: Bollati Boringhieri.

Caillé, Alain (2005). Anti-Utilitarianism, Economics and the Gift-Paradigm, URL:

http://www.revuedumauss.com.fr/media/ACstake.pdf.

Carabelli, Anna (1988). On Keynes's Method. London: Macmillan.

Carabelli, Anna (1991). The Methodology of the Critique of the Classical Theory: Keynes on Organic Interdependence, in: B.W. Bateman and John B. Davis (eds.), Keynes and Philosophy. Aldershot: Edward Elgar: 104-125.

Carabelli, Anna (1998). Keynes on Probability, Uncertainty and Tragic Choices, Cahiers d'économie politique. 30-31: 187-226.

Carabelli, Anna and Mario Cedrini (2009). The Economic Problem of Happiness. Keynes on Happiness and Economics, SEMeQ Working Paper 13/09.

Carabelli, Anna and Mario Cedrini (2010a). Current Global Imbalances: Might Keynes Be of Help?, in: M.C. Marcuzzo, T. Hirai and B.W. Bateman (eds.), The Return to Keynes. Cambridge, Mass.: Harvard University Press: 257-274. 
Carabelli, Anna and Mario Cedrini (2010b). Keynes and the Complexity of International Economic Relations in the Aftermath of World War I, Journal of Economic Issues. 44(4). Forthcoming.

Carabelli, Anna and Mario Cedrini (2010c). Global Imbalances, Monetary Disorder, and Shrinking Policy Space: Keynes's Legacy for Our Troubled World, Intervention. European Journal of Economics and Economic Policies. 7(2). Forthcoming.

Carabelli, Anna and Niccolò De Vecchi (1999). 'Where to Draw the Line'? Keynes Versus Hayek on Knowledge, Ethics and Economics, The European Journal of the History of Economic Thought. 6(2): 271296.

Carabelli, Anna and Niccolò De Vecchi (2001). Individuals, Public Institutions and Knowledge: Hayek and Keynes, in: P. Porta, R. Scazzieri and A. Skinner, A. (eds.), Knowledge, Social Institutions and the Division of Labour. Aldershot: Elgar: 229-248.

Cedrini, Mario (2010). A Maussian View of Keynes's Economic Diplomacy, Paper presented to the Workshop 'Revisiting the Boundaries of Economics: A Historical Perspective', Collegio Carlo Alberto, Moncalieri (Torino), 16 April.

Chinn, Menzie D. (2005). Getting Serious About the Twin Deficits, Council on Foreign Relations Special Report 10, September, URL: http://www.cfr.org/content/publications/attachments/ TwinDeficitsTF.pdf.

Davidson, Paul (2009). The Keynes Solution: The Path to Global Economic Prosperity. New York: Palgrave Macmillan.

De Cecco, Marcello (1977). The Last of the Romans, in: R. Skidelsky (ed.), The End of the Keynesian Era. Essays on the Disintegration of the Keynesian Political Economy. New York: Holmes \& Meier: 18-24.

De Cecco, Marcello (1979). Origins of the Post-war Payments System, Cambridge Journal of Economics. 3(1): 4961.

De Cecco, Marcello (1990). Keynes Revived. A Review Essay, Journal of Monetary Economics. 26(1): 179-190.

De Cecco, Marcello (2001). John Maynard Keynes, Rivista di storia economica, 17(3): 373-382.

Dillard, Dudley (1946). The Pragmatic Basis of Keynes's Political Economy, Journal of Economic History. 6: 121152.

Dimand, Robert W. (2006): Keynes and Global Economic Integration, Atlantic Economic Journal. 34(2): 175-182.

Dimsdale, Nicholas H. (1975). Keynes and the Finance of the First World War, in: M. Keynes, (ed.), Essays on John Maynard Keynes. London-New York: Cambridge University Press, 142-161.

Elliott, John E., and Hans E. Jensen, (1997). John Maynard Keynes on Socio-Economic Classes in Twentieth-Century Capitalism, in: J.P. Henderson, The State of the History of Economics. London and New York: Routledge: 105-129.

Ferrari Bravo, Giuliano (1990). Keynes. Uno studio di diplomazia economica. Padova: Cedam.

Fleming, Grant (2000). Foreign Investment, Reparations And the Proposal for an International Bank: Notes 
on the Lectures of J. M. Keynes in Geneva, July 1929, Cambridge Journal of Economics. 24(2): 139-151.

Gardner, Richard N. (1980). Sterling-Dollar Diplomacy. Oxford: Oxford University Press.

Godbout, Jacques T. (1998). The Moral of the Gift, The Journal of Socioeconomics. 27(4), 557-570.

Godbout, Jacques T., in collaboration with Alain Caillé (2000). The World of the Gift, Montreal: McGill-Queen's University Press.

Gouldner, Alvin W. (1973). For Sociology. Renewal and Critique in Sociology Today. London: Allen Lane.

Harrod, Roy F. (1951). The Life of John Maynard Keynes. New York: Harcourt, Brace and Company.

Harrod, Roy F. (1948). Towards a Dynamic Economics. London: Macmillan.

Helburn, Suzanne W. (1992). On Keynes's Ethics, in: P. Arestis and V. Chick (eds.), Recent Development in Post-Keynesian Economics. Aldershot: Elgar: 27-46.

Keynes, John M. (1905): Miscellanea Ethica, in: King's College Archive Centre, Cambridge, The Papers of John Maynard Keynes.

Keynes, John M. (1971-1989). The Collected Writings of John Maynard Keynes, edited by Elizabeth Johnson and Donald E. Moggridge. London: Macmillan.

Vol. 2. The Economic Consequences of the Peace [1919], 1971.

Vol. 4 A Tract on Monetary Reform [1923], 1971.

Vol. 6. A Treatise on Money: II. The Applied Theory of Money [1930], 1971.

Vol. 7. The General Theory of Employment, Interest and Money [1936], 1973.

Vol. 9. Essays in Persuasion [1931], 1972.

Vol. 10. Essays in Biography [1933], 1972.

Vol. 12. Economic Articles and Correspondence: Investment and Editorial, 1983.

Vol. 13 The General Theory and After: Part I, Preparation, 1973.

Vol. 14. The General Theory and After: Part II, Defence and Development, 1973.

Vol. 16. Activities 1914-19: The Treasury and Versailles, 1971.

Vol. 17. Activities 1920-22: Treaty Revision and Reconstruction, 1971.

Vol. 18. Activities 1922-32: The End of Reparations, 1978.

Vol. 19 Activities 1922-29: The Return to Gold and Industrial Policy, 2 vols, 1981

Vol. 21. Activities 1931-39: World Crisis and Policies in Britain and America, 1982.

Vol. 22 Activities 1939-1945: Internal War Finance, 1978.

Vol. 23 Activities 1940-1943: External War Finance, 1979.

Vol. 24. Activities 1944-1946: The Transition to Peace, 1979.

Vol. 25. Activities 1940-44: Shaping the Post-War World: The Clearing Union, 1980.

Vol. 26 Activities 1941-46: Shaping the Post-War World: Bretton Woods and Reparations, 1980.

Vol. 28 Social, Political and Literary Writings, 1982.

Kirshner, Jonathan (2009). Keynes, Legacies and Inquiries, Theory and Society. 38(5): 527-541. 
Kregel, Jan A. (2006). Understanding Imbalances in a Globalised International Economic System, in:

J.J. Teunissen and A. Akkerman (eds.), Global Imbalances and the US Debt Problem. Should

Developing Countries Support the US Dollar?. The Hague: Fondad: 149 - 173.

Marchionatti, Roberto (2010): J.M.Keynes, Thinker of Economic Complexity, History of Economic Ideas. 18(2): 115-146.

Marcuzzo, Maria C. (2008). Keynes and Persuasion, in: M. Forstater and L.R. Wray (eds.), Keynes for the 21st Century: The Continuing Relevance of the General Theory. London: Palgrave-Macmillan: 23-40.

Meltzer, Allan H. (1989). Keynes's Monetary Theory: A Different Interpretation. Cambridge: Cambridge University Press.

Mini, Piero V. (1994). John Maynard Keynes. A Study in the Psychology of Original Work. New York: St. Martin's Press.

Mini, Piero V. (2006). Keynes, Schacht and the 'New Order', Paper presented to the EABR \& ETLC Conference, Firenze, 29 June.

Moggridge, Donald E. (1986): Keynes and the International Monetary System 1909-46, in: J.S. Cohen, and G.C. Harcourt (eds.), International Monetary Problems and Supply-Side Economics: Essays in Honour of Lorie Tarshis. London: Macmillan: 56-83.

Moggridge, Donald E. (1992). Maynard Keynes: An Economist's Biography. London: Routledge.

Moggridge, Donald E. (2002): Skidelsky on Keynes: A Review Essay, History of Political Economy. 34(3): 633655.

Newton, Scott (2000): A 'Visionary Hope' Frustrated: J.M. Keynes and the Origins of the Postwar International Monetary Order, Diplomacy and Statecraft. 11(1): 189 - 210.

O'Donnell, Roderick M. (1989). Keynes: Phylosophy, Economics and Politics. The Philosophical Foundations of Keynes's Thought and Their Influence on his Economics and Politics. London: Macmillan.

Pressnell, Leslie S. (1986). External Economic Policy since the War. Vol. 1: The Post-War Financial Settlement. London: Her Majesty's Stationery Office.

Rodrik, Dani (2010). Who Lost Europe?, Project Syndicate. URL: http://www.projectsyndicate.org/commentary/rodrik44/English.

Roubini, Nouriel (2010). How to Avoid a Double-Dip Global Recession, Project Syndicate. URL: http://www.project-syndicate.org/commentary/roubini26/English.

Sahlins, Marshall (1972). Stone Age Economics. Chicago and New York: Aldine Publishing Company.

Skidelsky, Robert (1992). John Maynard Keynes. Vol. 2: The Economist as Saviour. London: Macmillan.

Skidelsky, Robert (2000). John Maynard Keynes. Vol. 3: Fighting for Britain, 1937- 1946. London: Macmillan.

Skidelsky, Robert (2009). Keynes. The Return of the Master. London: Penguin.

Soros, George (2010). Germany's Europe Deficit, Project Syndicate. URL: http://www.projectsyndicate.org/commentary/soros59/English. 
Stiglitz, Joseph E. (2010). Can the Euro Be Saved?, Project Syndicate. URL: http://www.projectsyndicate.org/commentary/stiglitz125/English.

Turnell, Sean (2002). Keynes, Economics and War: A Liberal Dose of Realism, Research Papers of the Department of Economics of Macquarie University, 0207.

Zenou, Yves, Philippe Batifoulier and Laurent Cordonnier (1992). L'Emprunt de la Théorie Économique à la Tradition Sociologique. Le Cas du Don Contre-Don, Revue économique. 43(5): 917-946. 